\title{
Selenium substitution effect on crystal structure of stibnite $\left(\mathrm{Sb}_{2} \mathrm{~S}_{3}\right)$
}

\author{
Atsushi Kyono ${ }^{1,}{ }^{*}$, Akinobu Hayakawa, ${ }^{2}$ and Mayumi Horiki ${ }^{2}$
}

${ }^{1}$ Division of Earth Evolution Sciences, Graduate School of Life and Environmental Sciences,

University of Tsukuba, 1-1-1 Tennodai, Tsukuba, Ibaraki 305-8572, Japan

${ }^{2}$ High Performance Plastics Company, Sekisui Chemical Co., Ltd.

2-1 Hyakuyama, Shimamoto Chou, Mishima Gun, Osaka 618-0021, Japan

Correspondence author: A. Kyono

Address: Division of Earth Evolution Sciences, Graduate School of Life and Environmental Sciences,

University of Tsukuba, 1-1-1 Tennodai, Tsukuba, Ibaraki 305-8572, Japan

Correspondence e-mail: kyono@geol.tsukuba.ac.jp

Phone: +81-29-853-7176, Fax: +81-29-853-7887 


\section{ABSTRACT}

Composition dependence of the crystal structure between stibnite and antimonselite is investigated by using the single-crystal x-ray diffraction and the ab-initio calculation methods to clarify the Se substitution effect on the crystal structure, especially focusing on the stereochemical behavior of $\mathrm{Sb}$ $5 s^{2}$ lone pair electrons. The single-crystal x-ray diffraction measurements indicate no phase change throughout the solid solution range. The lattice parameters of $a, b, c$ and unit cell volume are linearly increased as Se content increases. The lattice parameter variations normalized show an anisotropic expansion that the largest expansion is observed along the $\boldsymbol{a}$-axis, followed by the $\boldsymbol{c}$ and $\boldsymbol{b}$-axes. The large Se atom exhibits a strong site preference for the $\mathrm{X}(1)$ and $\mathrm{X}(3)$ sites, while the small $\mathrm{S}$ atom prefers to occupy the $\mathrm{X}(2)$ site. The intra-ribbon $\mathrm{Sb}(1)-\mathrm{X}$ and $\mathrm{Sb}(2)-\mathrm{X}$ distances $(\mathrm{X}=\mathrm{S}, \mathrm{Se})$ are continuously increased with the $\mathrm{Se}$ content. The three $\mathrm{Sb}(1)$-X bond distances in the trigonal pyramids are changed within the similar range between 2.52 and $2.68 \AA$, while the five $\mathrm{Sb}(2)$-X distances in the tetragonal pyramids vary from 2.45 to $2.59 \AA$, from 2.68 to $2.80 \AA$, and from 2.86 to $3.00 \AA$, respectively. With increasing Se content in the solid solution, the inter-ribbon distances where the $\mathrm{Sb}$ $5 s^{2}$ LPEs are located monotonously increase as well. However, the variations between the ribbons are considerably smaller than those of intra-ribbon distances. The polyhedral volumes of the $\mathrm{Sb}(1) \mathrm{X}_{7}$ and $\mathrm{Sb}(2) \mathrm{X}_{7}$ in which the $\mathrm{Sb} 5 \mathrm{~s}^{2}$ LPEs are accommodated constantly increase from 35.9 to $40.0 \AA^{3}$ and from 34.1 to $38.8 \AA^{3}$, respectively, and these eccentricity parameters decrease from 0.66 to 0.62 and 
from 0.57 to 0.55 . As a result of ab-initio calculation, the $\mathrm{Sb} 5 \mathrm{~s}$ orbitals on the $\mathrm{Sb}(1)$ atoms remain almost unchanged throughout the solid solution. On the other hand, the those on the $\mathrm{Sb}(2)$ atoms become smaller with the incorporation of Se. The result gives a more reasonable interpretation that the stereochemistry of $\mathrm{Sb} 5 \mathrm{~s}^{2}$ LPEs and the stereochemisry of the coordination polyhedra around the $\mathrm{Sb}$ atoms are affected by the Se substitution in the structure.

Key words: stibnite, antimonselite, stereochemical activity, single-crystal x-ray diffraction, ab-initio calculation 


\section{INTRODUCTION}

Stibnite $\left(\mathrm{Sb}_{2} \mathrm{~S}_{3}\right)$ is an antimony sulfide mineral which occurs most commonly in hydrothermal vein and replacement deposits of low-temperature origin (e.g., Wood et al. 1987; Krupp 1988; Gaines et al. 1997). It is found in association with minerals such as realgar, orpiment, cinnabar, galena, pyrite, arsenopyrite, calcite, and quartz (Anthony et al. 1990). The crystal structure consists of parallel $\left(\mathrm{Sb}_{4} \mathrm{~S}_{6}\right)_{\mathrm{n}}$ ribbon-like chains held together with the weaker intermolecular forces (Hofmann 1933; Scavnicar 1960; Bayliss and Nowacki 1972). In the crystal structure, Sb atoms in a trivalent state are distributed over two different crystallographic sites. The two crystallographically independent $\mathrm{Sb}$ atoms exhibit a characteristic one-sided coordination because of the stereochemical activity of inert $5 s^{2}$ lone-pair electrons (LEPs) of the Sb atoms (Kyono et al. 2002; Kyono and Kimata 2004). One shows a trigonal $\mathrm{SbS}_{3}$ pyramid with the $\mathrm{Sb}$ atom at the vertex, and another forms an $\mathrm{SbS}_{5}$ square pyramid with the $\mathrm{Sb}$ atom at the centre. An isomorphic mineral of the stibnite, antimonselite $\mathrm{Sb}_{2} \mathrm{Se}_{3}$, has also been known (Chen et al. 1993; Jambor and Grew 1994; Min et al. 1998). Liu et al. (2008) indicated that there is a continuous solid solution between stibnite and antimonselite. The Se/S ratios can be used as a typical geochemical indicator of deposition in a volcanic environment because the $\mathrm{Se} / \mathrm{S}$ ratio is useful for determining not only the sources of $\mathrm{S}$ but also geothermometry and the redox gradients (Anderson 1969; Huston et al. 1995). A variety of stereochemical activities induced by the LPEs drastically affect configuration of stibnite because the $\mathrm{Sb} 5 \mathrm{~s}^{2}$ LPEs are interposed between the 
ribbon-like chains running along the $\boldsymbol{b}$-axis (Kyono and Kimata 2004). Thus, the stereochemically active LPEs play an important role in determining the structural stability. It has been known that a phase transition in a stibiocolumbite-bismutocolumbite solid solution is caused by varying degree of stereochemical activity (Kazantsev et al. 2002). However, little is known about the detailed influence of substitution of $\mathrm{S}$ with $\mathrm{Se}$ on the stereochemical activities of $\mathrm{Sb} 5 \mathrm{~s}^{2}$ LPEs and crystal structure. Recently, the $\mathrm{Sb}_{2} \mathrm{~S}_{3}$ and $\mathrm{Sb}_{2} \mathrm{Se}_{3}$ have been enthusiastically studied as one of the most promising materials for low cost and high efficiency thin film solar cells (Fernández and Merino 2000; Rajpure and Bhosale 2000, 2002; Zheng et al. 2002; Messina et al. 2009; Patrick and Giustino 2011; Choi et al 2014). The thin films with the composition of $\mathrm{Sb}_{2} \mathrm{~S}_{\mathrm{x}} \mathrm{Se}_{3-\mathrm{x}}$ have an optical band gap of 1.3-1.7 eV along the thickness (Messina et al. 2007), which would be an attractive feature for solar cells. In order to comprehend the electronic structure of the materials, it is necessary to fully understand the behavior of crystal structure, stereochemical activity of $\mathrm{Sb} 5 \mathrm{~s}^{2} \mathrm{LEPs}$, and distribution of the anions within the range from $\mathrm{Sb}_{2} \mathrm{~S}_{3}$ to $\mathrm{Sb}_{2} \mathrm{Se}_{3}$.

Here we present the results of the single-crystal x-ray diffraction study of the compositions between stibnite and antimonselite and the ab-initio theoretical study of the electronic structures. The experimental and theoretical results obtained in the present study clearly show the Se substitution effect on the crystal structure, especially focusing on the stereochemical behavior of $\mathrm{Sb} 5 \mathrm{~s}^{2} \mathrm{LPEs}$ in the solid solution. 


\section{EXPERIMENTAL METHODS}

Commercially available Sb (Wako Pure Chemical, purity > 99.5\%), S (Wako Pure Chemical, purity $>98.0 \%$ ), and Se metal (Wako Pure Chemical, purity $>99.0 \%$ ) were used as starting materials. Compositions of the starting mixtures were as follows: Sb:S:Se ratio of (1) $2: 3: 0$, (2) $2: 2.25: 0.75$, (3) $2: 1.5: 1.5$, (4) $2: 0.75: 2.25$, and (5) $2: 0: 3$. The mixed powders were sealed under vacuum in a quartz vessel. It was subsequently placed into a furnace and heated at $500{ }^{\circ} \mathrm{C}$ for $96 \mathrm{~h}$. Finally, elongated prismatic single crystals with a length of $100-300 \mu \mathrm{m}$ were obtained.

For single-crystal x-ray diffraction measurements, suitable single crystals were fixed on a $0.1 \mathrm{~mm}$ diameter glass fiber, and then mounted on a RAXIS-RAPID imaging plate diffractometer (Rigaku Corp.) operating with MoKa radiation $(\lambda=0.71069 \AA)$ monochromatized using a flat graphite crystal. A data set of 44 images was collected using an $\omega$-oscillation method with $5.0^{\circ}$ oscillation step between 130 and $190^{\circ}\left(\chi=45^{\circ}, \varphi=0^{\circ}\right)$ and between 0 and $160^{\circ}\left(\chi=45^{\circ}, \varphi=180^{\circ}\right)$. The exposure rate was of 180 s per degree of the oscillation. Intensities were corrected for Lorentz and polarization effects. An absorption correction was applied from the symmetry-equivalent reflections using the ABSCOR program (Higashi 1995). The structure was solved using direct methods with the SIR97 program package (Altomare et al. 1999). Only reflections with $I_{0}>4 \sigma\left(I_{0}\right)$ were used for structure refinements performed using full-matrix least squares on $F^{2}$ with the CRYSTALS program (Carruthers et al. 1999). 
After the all x-ray diffraction measurements, each single crystal was removed and mounted in epoxy. Then it was polished using a $1 \mu \mathrm{m}$ diamond suspension for the electron microprobe analysis. Quantitative chemical analysis was performed with the JXA-8530F electron probe micro-analyzer (JEOL Ltd.) equipped with a wavelength-dispersive x-ray spectrometer. The samples were probed with an acceleration voltage of $15 \mathrm{kV}$, an irradiation current of $10 \mathrm{nA}$, and a beam diameter of $1 \mu \mathrm{m}$. The chemical composition of each crystal was determined from the averages of several points analyzed. Raw data were corrected using a conventional ZAF program. Synthetic $\mathrm{Sb}_{2} \mathrm{~S}_{3}(\mathrm{Sb} L \alpha$ and $\mathrm{S} K \alpha$ ) and synthetic $\mathrm{Sb}_{2} \mathrm{Se}_{3}(\mathrm{Se} L \alpha)$ were used as standards. Empirical formulae were normalized on the basis of five atoms per formula unit. Site occupancies were refined within the constraint that three $\mathrm{X}$ sites $(\mathrm{X}$ $=\mathrm{S}, \mathrm{Se}$ ) are occupied fully by the $\mathrm{S}$ and $\mathrm{Se}$ atoms. Based on the assumption that the $\mathrm{S}$ and $\mathrm{Se}$ atoms are disordered at three $\mathrm{X}$ sites, the ratio between $\mathrm{S}$ and $\mathrm{Se}$ was refined under the constraint that total S/Se ratio is equal to the chemical composition determined with the electron microprobe analyses. Data collection and refinement details are reported in Table 1. The final atomic positions and their chemical compositions are presented in Table 2. All bond lengths and bond angles are given in Table 3.

Ab-initio calculations of the electronic structure were performed at DFT/B3LYP/3-21+G basis set using the quantum chemical calculation software package Gaussian-09 (Frisch et al. 2009). Initial structure models were built based on the atomic coordinates experimentally determined by the x-ray 
diffraction measurement in the present study. The dimension of the simulation region includes four characteristic ribbon-like chains. To terminate an infinite crystal structure, hydrogen atoms were added as a positive charge on the $\mathrm{S}$ and $\mathrm{Se}$ atoms at the terminal positions. The orbital surfaces were rendered with the GaussView molecular visualization package (Dennington et al. 2009). The orbitals were drawn at an interface value of 0.02 .

\section{RESULTS AND DISCUSSION}

The single-crystal x-ray diffraction measurements indicate no phase change occurs throughout the solid solution range. The $\mathrm{Sb}_{2} \mathrm{~S}_{3-\mathrm{x}} \mathrm{Se}_{\mathrm{x}}(0 \leq x \leq 3)$ can form a complete solid solution between $\mathrm{Sb}_{2} \mathrm{~S}_{3}$ and $\mathrm{Sb}_{2} \mathrm{Se}_{3}$. The variations in lattice parameters are summarized in Figure 1. Data were fitted by a leastsquares regression to the second degree polynomial curve. With increasing Se content, the lattice parameters of $\boldsymbol{a}, \boldsymbol{b}$, and $\boldsymbol{c}$ are linearly increased from 11.33 to $11.80 \AA$, from 3.84 to $3.99 \AA$, and from 11.25 to $11.65 \AA$, respectively. As a result of expansion of the lattice parameters, the unit cell volume undergoes a monotonous increase from 489 to $548 \AA^{3}$ as a function of the Se content (Table 1). The lattice parameter variations normalized to the minimum values show an anisotropic expansion of the lattice parameters against the Se content (Fig. 1d). The largest expansion is observed along the $\boldsymbol{a}$-axis, followed by the $\boldsymbol{c}$ and $\boldsymbol{b}$-axes (Fig. 1d). The anisotropic behavior with the Se content is exactly identical to those induced by compression (Lundegaard et al. 2003). At a temperature range from 128 to $298 \mathrm{~K}$, 
the largest thermal expansion occurs along the $\boldsymbol{c}$-axis, followed by the $\boldsymbol{a}$, and $\boldsymbol{b}$-axes (Kyono et al. 2002). The anisotropic behavior of the orthorhombic lattice is reflected by the structural characteristic feature. As can be seen in Figure 2a, there are a lying trigonal pyramid at the $\mathrm{Sb}(1)$ position and a standing tetragonal pyramid at $\mathrm{Sb}(2)$ position along the $\boldsymbol{b}$-axis. The $\boldsymbol{b}$-axis direction is most rigid due to the strong bonded ribbon structure, which reflects the smallest expansion behavior of $\boldsymbol{b}$-axis. On the other hand, the space between the ribbons running parallel to $\boldsymbol{b}$-axis accommodates the $\mathrm{Sb} 5 \mathrm{~s}^{2}$ LPEs. Because the electron density is concentrated within the ribbons, $\mathrm{Sb}-\mathrm{X}(\mathrm{X}=\mathrm{S}, \mathrm{Se})$ bonds between ribbons become much weaker than those within the ribbons. That is, the $\boldsymbol{a}$-and $\boldsymbol{c}$-axes directions are most variable due to the weak interactions between the ribbons. The site-occupancy parameters of Se over the three $\mathrm{X}$ sites are plotted in Figure 3. The large Se atom exhibits a strong site preference for the $X(1)$ and $X(3)$ sites, while the small $S$ atom prefers to occupy the $X(2)$ site. This is because the atomic positions of $X(1)$ and $X(3)$ can maintain the longer distance from Sb atoms than the $X(2)$ position.

The variations of the intra-ribbon $\mathrm{Sb}-\mathrm{X}$ distances are shown in Figures 4 and 5. The intra-ribbon $\mathrm{Sb}(1)-\mathrm{X}$ and $\mathrm{Sb}(2)-\mathrm{X}$ distances are continuously increased with the Se content. The three $\mathrm{Sb}(1)-\mathrm{X}$ bond distances in the trigonal pyramids are changed within the similar range of 2.52 to $2.68 \AA$, while the five $\mathrm{Sb}(2)-\mathrm{X}$ distances in the tetragonal pyramids vary from 2.45 to $2.59 \AA$, from 2.68 to $2.80 \AA$, and from 2.86 to $3.00 \AA$, respectively (Figs 4, 5). Although the ranges are considerably different from 
one another, the variations of the $\mathrm{Sb}(1)$-X distances exhibit similar elongation behavior to the $\mathrm{Sb}(2)$ -

$\mathrm{X}$. That is, since the short bondings possess a strong electrostatic interaction between $\mathrm{Sb}$ and $\mathrm{S} / \mathrm{Se}$ atoms, the short bond distances are more changeable than the long bond distances by the substitution of $\mathrm{S}$ with $\mathrm{Se}$ (Figs 4d, 5d). The $\mathrm{Sb}(1)-\mathrm{X}(2)$ distance located within the ribbon-like structure changes from 3.12 to $3.22 \AA$ with the Se content (Fig 4c). The slight variation of the $\mathrm{Sb}(1)-\mathrm{X}(2)$ distance is due to the rather long distance over $3.10 \AA$ (Fig. 4d).

The variations of the inter-ribbon $\mathrm{Sb}-\mathrm{X}(\mathrm{X}=\mathrm{S}, \mathrm{Se})$ distances are given in Figure 6. As the $\mathrm{Se}$ content increases in the solid solution, the inter-ribbon distances where the $\mathrm{Sb} 5 \mathrm{~s}^{2} \mathrm{LPEs}$ are located monotonously increase as well. With the substitution of $\mathrm{S}$ with $\mathrm{Se}$, the $\mathrm{Sb}(1)-\mathrm{X}(1)$ and $\mathrm{Sb}(2)-\mathrm{X}(3)$ distances are extended from 3.64 to $3.74 \AA$, and from 3.38 to $3.48 \AA$, respectively (Figs 6b, 6c). However, the variations between the ribbons are considerably smaller than those of intra-ribbon distances. The electron density of $\mathrm{Sb} 5 \mathrm{~s}^{2}$ lone pair electrons is fairly smaller than those of antimony atoms. Only the $\mathrm{Sb} 5 \mathrm{~s}^{2}$ lone pair electrons can't be observed within the electron density distribution of antimony atoms. In order to assess the Se substitution effect on the stereochemical activity of $\mathrm{Sb}$ $5 s^{2}$ LEPs, therefore, the polyhedral volumes and eccentric parameters of two sevenfold coordinations including the LPEs (Fig. 2b) are calculated by the IVTON program (Balić-Žunić and Vickovic 1996). The polyhedral volumes of the $\mathrm{Sb}(1) \mathrm{X}_{7}$ and $\mathrm{Sb}(2) \mathrm{X}_{7}$ constantly increase from 35.9 to $40.0 \AA^{3}$ and from 34.1 to $38.8 \AA^{3}$, respectively (Fig. 7a, 7b). The eccentric parameter is defined as the deviation of 
central atom position from the ideal metric centre of the coordination. That is, the larger the eccentricity suggests the larger stereochemical activity. As it can be seen from Figures $7 \mathrm{c}$ and $7 \mathrm{~d}$, the stereochemical deformation seems to decrease from 0.66 to 0.62 at $\mathrm{Sb}(1) \mathrm{X}_{7}$ and from 0.57 to 0.55 at $\mathrm{Sb}(2) \mathrm{X}_{7}$ with increase of the Se concentration. The stereochemical activity in the $\mathrm{Sb}(1) \mathrm{X}_{7}$ polyhedron is larger than that in the $\mathrm{Sb}(2) \mathrm{X}_{7}$ polyhedron. In the solid solution between $\mathrm{Sb}_{2} \mathrm{~S}_{3}$ and $\mathrm{Bi}_{2} \mathrm{~S}_{3}$ (Kyono and Kimata, 2005), however, the eccentric parameter drastically decreases with the Bi concentration from 0.66 to 0.42 at the $\mathrm{M}(1) \mathrm{X}_{7}$ coordination $(\mathrm{M}=\mathrm{Sb}, \mathrm{Bi})$ and from 0.57 to 0.48 at the $\mathrm{M}(2) \mathrm{X}_{7}$ coordination. A more reasonable interpretation is therefore presented that the stereochemistry of $\mathrm{Sb}$ $5 \mathrm{~s}^{2}$ LPEs is only slightly affected by the Se substitution in the crystal structure.

During the past decade, several first principle studies have been carried out on the structural and electronic properties of $\mathrm{Sb}_{2} \mathrm{~S}_{3}$ and $\mathrm{Sb}_{2} \mathrm{Se}_{3}$ (Caracas and Gonze 2005; Patrick and Giustino, 2011; Koc et al. 2012; Filip et al. 2013). The valence electron density, the electron band structure, and the corresponding electronic density-of-states were examined using the density functional theory (Koc et al. 2012). The authors determined the valence-band energy levels in the structures. As the results, the highest occupied valence bands are essentially dominated by S 3p, Se 4p, and $\mathrm{Sb} 5 \mathrm{p}$ states. The $\mathrm{Sb} 5 \mathrm{~s}$ states dominate the second energy group with small electronic density-of-states of the $S 3 \mathrm{~s}, 3 \mathrm{p}$ and the Se $4 s, 4 p$. Figure 8 shows the molecular orbitals associated with the stereochemical activity of Sb $5 s^{2}$ LPEs. In the energy level of $\mathrm{Sb}_{2} \mathrm{~S}_{3}$ (Fig. 8a), the $\mathrm{Sb} 5 \mathrm{~s}$ orbitals occupy the overlying spaces of the $\mathrm{Sb}$ 
atoms, resulting in a formation of the characteristic one-sided coordination of the $\mathrm{Sb}$ atom. A few $\mathrm{Sb}$ atoms without the characteristic LPEs are also observed. In the study, the dimension of the simulation region includes four ribbon-like chains. As it can be seen in the Fig. 8a, the electronic orbitals are almost equally spread over a whole ribbon. On the other hand, the electronic orbitals in the structure introducing a small amount of Se atoms are shown in Fig.8b. Since the Se atom exhibits a strong site preference for the $\mathrm{X}(1)$ (Fig. 3), the Se atoms are distributed on the $\mathrm{X}(1)$ sites in the structure. The most noteworthy finding is that the electronic orbitals are highly delocalized with substitution of Se for $\mathrm{S}$ atoms (Fig. 8 b). Compared with the pure $\mathrm{Sb}_{2} \mathrm{~S}_{3}$, most electronic orbitals are reduced in the two ribbons lying on the upper and lower ribbons. The $\mathrm{Sb} 5 \mathrm{~s}$ orbitals on the $\mathrm{Sb}(1)$ atoms remain almost unchanged, whereas those on the $\mathrm{Sb}(2)$ atoms in the upper and lower side become smaller with the incorporation of Se into the structure (Fig. 8b). The electronic orbitals in the $\mathrm{Sb}_{2} \mathrm{Se}_{3}$ are displayed in Fig. 8c. It exhibits an essentially similar feature to that of the $\mathrm{Sb}_{2}\left(\mathrm{~S}_{2} \mathrm{Se}\right)_{3}$ (Fig. 8b). The highly

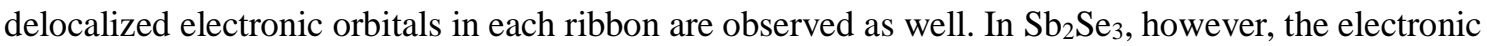
orbitals distributed in the two ribbons lying on the upper and lower ribbons are much reduced compared with those of the $\mathrm{Sb}_{2}\left(\mathrm{~S}_{2} \mathrm{Se}\right)_{3}$. Accordingly, the electronic orbitals in stibnite are significantly influenced by the Se substitution for $\mathrm{S}$ atoms. The results of the ab-initio theoretical study are approximately consistent with those of the x-ray diffraction measurement given in Figures $7 \mathrm{c}$ and $7 \mathrm{~d}$. In the structure, stereochemical arrangement is caused by the repulsive electrostatic interaction 
between the LPEs of the stereochemically active central Sb atom and coordinated ligands. That is, the stereochemistry in the structure would be affected not only by the $\mathrm{Sb} 5$ s orbitals but the highest occupied valence bands dominated by S 3p, Se 4p, and Sb 5p. The electronic orbitals of the S $3 p, S e$ $4 \mathrm{p}$, and $\mathrm{Sb} 5 \mathrm{p}$ are not considered in the study, but the ab-initio calculation reveals that the electronic orbitals, especially $\mathrm{Sb} 5 \mathrm{~s}$ orbitals, are drastically affected by the incorporation of $\mathrm{Se}$ into the stibnite structure. As mentioned before, the change in stereochemical configuration induced by the Se substitution is smaller than that caused by the Bi substitution (Kyono and Kimata, 2005), although variations of the $a$ and $c$ lattice parameters between $\mathrm{Sb}_{2} \mathrm{~S}_{3}$ and $\mathrm{Sb}_{2} \mathrm{Se}_{3}$ are significantly larger than those between $\mathrm{Sb}_{2} \mathrm{~S}_{3}$ and $\mathrm{Bi}_{2} \mathrm{~S}_{3}$. In conclusion, the stereochemical feature of $\mathrm{Sb} 5 \mathrm{~s}^{2}$ LEPs and the stereochemisry of the coordination polyhedra around the $\mathrm{Sb}$ atoms can be reduced with the $\mathrm{Se}$ substitution for $\mathrm{S}$ in stibnite. 


\section{ACKNOWLEDGMENTS}

We thank E. Makovicky and an anonymous reviewer for their constructive comments and T.

Tsuchiya for editorial handling. We are grateful to N. Chino for kindly providing technical help with the EPMA analyses. The work was partially supported by a Grant-in-Aid for Young Scientists (B) from the Japan Society for the Promotion of Science (project no. 24740352).

\section{REFERENCES}

Altomare A, Burla MC, Camalli M, Cascarano GL, Giacovazzo C, Guagliardi A, Moliterni AGG, Polidori G, Spagna R (1999) SIR97: a new tool for crystal structure determination and refinement. Journal of Applied Crystallography 32: 115-119

Anderson CA (1969) Massive sulfide deposits and volcanism. Economic Geology 64: 129-146

Anthony JW, Bideaux RA, Bladh KW, Nichols MC (1990) Handbook of mineralogy Vol. I. Elements, Sulfides, Sulfosalts. Mineral Data Publishing, Tucson, Arizona, p498

Balić-Žunić T, Vickovic I (1996) IVTON—program for the calculation of geometrical aspects of crystal structures and some crystal chemical applications. Journal of Applied Crystallography 29: 305-306

Bayliss P, Nowacki W (1972) Refinement of the crystal structure of stibnite, $\mathrm{Sb}_{2} \mathrm{~S}_{3}$. Zeitschrift für Kristallographie 135: 308-315 
Caracas R, Gonze X (2005) First-principles study of the electronic properties of $A_{2} B_{3}$ minerals, with $\mathrm{A}=\mathrm{Bi}, \mathrm{Sb}$ and B=S,Se. Physics and Chemistry of Minerals, 32: 295-300

Carruthers JR, Rollett JS, Betteridge PW, Kinna D, Pearce L, Larsen A, Gabe E (1999) CRYSTALS No. 11. Chemical Crystallography Laboratory, Oxford, U.K.

Chen L, Zhang Q, Li D, Wang G (1993) Antimonelite: A new mineral. Acta Mineralogica Sinica 13: 7-11 (in Chinese with English abs.)

Choi YC, Mandal TN, Yang WS, Lee YH, Im SH, Noh JH, Seok SI (2014) $\mathrm{Sb}_{2} \mathrm{Se}_{3}$-sensitized inorganic-organic heterojunction solar cells fabricated using a single-source precursor. Angewandte Chemie International Edition 53: 1329-1333

Dennington R, Keith T, Millam J (2009) Gauss View, Version 5, Semichem Inc., Shawnee Mission KS Fernández AM, Merino MG (2000) Preparation and characterization of $\mathrm{Sb}_{2} \mathrm{Se}_{3}$ thin films prepared by electrodeposition for photovoltaic applications. Thin Solid Films 366: 202-206

Filip MR, Patrick CE, Giustino F (2013) GW quasiparticle band structures of stibnite, antimonselite, bismuthinite, and guanajuatite. Physical Review B, 87: 205125

Frisch MJ, Trucks GW, Schlegel HB, Scuseria GE, Robb MA, Cheeseman JR, Scalmani G, Barone V, Mennucci B, Petersson GA, Nakatsuji H, Caricato M, Li X, Hratchian HP, Izmaylov AF, Bloino J, Zheng G, Sonnenberg JL, Hada M, Ehara M, Toyota K, Fukuda R, Hasegawa J, Ishida M, Nakajima T, Honda Y, Kitao O, Nakai H, Vreven T, Montgomery Jr.JA, 
Peralta JE, Ogliaro F, Bearpark M, Heyd JJ, Brothers E, Kudin KN, Staroverov VN,

Kobayashi R, Normand J, Raghavachari K, Rendell A, Burant JC, Iyengar SS, Tomasi J,

Cossi M, Rega N, Millam JM, Klene M, Knox JE, Cross JB, Bakken V, Adamo C,

Jaramillo J, Gomperts R, Stratmann RE, Yazyev O, Austin AJ, Cammi R, Pomelli C,

Ochterski JW, Martin RL, Morokuma K, Zakrzewski VG, Voth GA, Salvador P,

Dannenberg JJ, Dapprich S, Daniels AD, Farkas Ö, Foresman JB, Ortiz JV, Cioslowski J,

Fox DJ, (2009) Gaussian 09, Revision A.1, Gaussian, Inc., Wallingford CT

Gaines RV, Skinner HCW, Foord EE, Mason B, Rosenzweig A (1997) Dana's new mineralogy: the system of mineralogy of James Dwight Dana and Edward Salisbury Dana, 8th ed. John Wiley, New York, p106

Higashi T (1995) Abscor-Empirical absorption correction based on Fourier series approximation.

Rigaku Corp. Tokyo

Hofmann W (1933) Die Struktur der Minerale der Antimonitgruppe. Zeitschrift für Kristallographie

86: $225-245$

Huston DL, Sie SH, Suter GF, Cooke DR, Both RA (1995) Trace elements in sulfide minerals from eastern Australian volcanic-hosted massive sulfide deposits: part I. Protein microprobe analyses of pyrite, chalcopyrite and sphalerite, and part II. Selenium levels in pyrite: comparison with $\delta 34 \mathrm{~S}$ values and implications for the source of sulfur in volcanogenic 
hydrothermal systems. Economic Geology 90: 1167-1196

Jambor JL, Grew ES (1994) New mineral names. American Mineralogist 79: 387-391

Kazantsev SS, Pushcharovsky DY, Maximov BA, Molchanov NV, Werner S, Schneider J, Sapozhnikov AN (2002) Phase transitions in solid solution series bismutocolumbitestibiocolumbite (Bi-Sb) $\left(\mathrm{Nb}_{0.79} \mathrm{Ta}_{0.21}\right) \mathrm{O}_{4}$. Zeitschrift für Kristallographie 217: 542-549

Koc H, Mamedov AM, Deligoz E, Ozisik H (2012) First principles prediction of the elastic, electronic, and optical properties of $\mathrm{Sb}_{2} \mathrm{~S}_{3}$ and $\mathrm{Sb}_{2} \mathrm{Se}_{3}$ compounds. Solid State Sciences, 14: 12111220

Krupp RE (1988) Solubility of stibnite in hydrogen sulfide solutions, speciation, and equilibrium constants, from 25 to $350^{\circ} \mathrm{C}$. Geochimica et Cosmochimica Acta 52: 3005-3015

Kyono A, Kimata M, Matsuhisa M, Miyashita Y, Okamoto K (2002) Low-temperature crystal

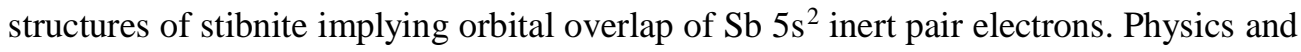
Chemistry of Minerals 29: 254-260

Kyono A, Kimata M (2004) Structural variations induced by difference of the inert pair effect in the stibnite-bismuthinite solid solution series $(\mathrm{Sb}, \mathrm{Bi})_{2} \mathrm{~S}_{3}$. American Mineralogist 89: $932-940$

Liu JJ, Liu JM, Li JL, Xie H, Wang JP, Deng J, Feng C, Qi F, Zhang N (2008) Experimental synthesis of the stibnite-antimonselite solid solution series. International Geology Review 50: 
$168-176$

Lundegaard LF, Miletich R, Balic-Zunic T, Makovicky E (2002) Equation of state and crystal structure of $\mathrm{Sb}_{2} \mathrm{~S}_{3}$ between 0 and $10 \mathrm{GPa}$. Physics and Chemistry of Minerals, 30: 463-468

Messina S, Nair MTS, Nair PK (2007) Antimony sulfide thin films in chemically deposited thin film photovoltaic cells. Thin Solid Films 515: 5777-5782 (2009) Antimony selenide absorber thin films in all-chemically deposited solar cells. Journal of the Electrochemical Society 156: H327-H332

Min MZ, Zhai JP, Wang XY, Shen BP, Wen GD, Fan, T (1998) Refinement of the crystal structure for a new mineral - antimonselite. Chinese Science Bulletin 43: 413-416

Patrick CE, Giustino F (2011) Structural and electronic properties of semiconductor-sensitized solarcell interfaces. Advanced Functional Materials 21: 4663-4667

Rajpure KY, Bhosale $\mathrm{CH}(2000) \mathrm{Sb}_{2} \mathrm{~S}_{3}$ semiconductor-septum rechargeable storage cell. Materials Chemistry and Physics 64: 70-74 (2002) Preparation and characterization of spray deposited photoactive $\mathrm{Sb}_{2} \mathrm{~S}_{3}$ and $\mathrm{Sb}_{2} \mathrm{Se}_{3}$ thin films using aqueous and non-aqueous media. Materials Chemistry and Physics 73: 6-12

Scavnicar S (1960) The crystal structure of stibnite. A redetermination of atomic positions. Zeitschrift 
für Kristallographie 14: 86-97

Wood SA, Crerar DA, Borcsik MP (1987) Solubility of the assemblage pyrite-pyrrhotite-magnetitesphalerite-galena-gold-stibnite-bismuthinite-argentite-molybdenite in $\mathrm{H}_{2} \mathrm{O}-\mathrm{NaCl}-\mathrm{CO}_{2}$ solutions from $200^{\circ} \mathrm{C}$ to $350^{\circ} \mathrm{C}$. Economic Geology 82: $\quad 1864-1887$

Zheng XW, Xie Y, Zhu LY, Jiang XC, Jia YB, Song WH, Sun YP (2002) Growth of $\mathrm{Sb}_{2} \mathrm{E}_{3}(\mathrm{E}=\mathrm{S}, \mathrm{Se})$ polygonal tubular crystals via a novel solvent-relief-self-seeding process. Inorganic Chemistry 41: 455-461 


\section{Captions for Figures and Tables}

Figure 1 The compositional dependence lattice parameters of (a) $a$, (b) $b$, and (c) $c$. (d) The variations of normalized lattice parameters divided by minimum values for each lattice parameter. Solid circles, open diamonds, and solid triangles stand for the $a / a_{0}, b / b_{0}$, and $c / c_{0}$, respectively. Data were fitted by a least-squares regression to the second degree polynomial curve. The error bars are smaller than the data points.

Figure 2 A ball-and-stick view of the crystal structure of $\mathrm{Sb}_{2} \mathrm{X}_{3}(\mathrm{X}=\mathrm{S}, \mathrm{Se})$ viewed in the direction of $b$-axis.

Figure 3 Site occupancy parameters for Se on the three $\mathrm{X}$ sites in the $\mathrm{Sb}_{2} \mathrm{~S}_{3-\mathrm{x}} \mathrm{Se}_{\mathrm{x}}$ solid solution. Solid circles, solid triangles, and open diamonds indicate the $\mathrm{X}(1), \mathrm{X}(2)$, and $\mathrm{X}(3)$ site, respectively.

Figure 4 Variations of Sb-X $(X=S, S e)$ bond lengths around the Sb1 site. The error bars are smaller than the data points.

Figure 5 Variations of $\mathrm{Sb}-\mathrm{X}(\mathrm{X}=\mathrm{S}, \mathrm{Se})$ bond lengths around the $\mathrm{Sb} 2$ site.

Figure 6 Variations of interatomic distances between the ribbons along the $b$-axis direction.

Figure 7 Variations of polyhedral volumes of $\mathrm{Sb}_{1} \mathrm{X}_{7}$ and $\mathrm{Sb} 2 \mathrm{X}_{7}$ and their polyhedral eccentric parameters calculated by the IVTON program (Balić-Žunić and Vickovic 1996).

Figure 8 Molecular orbitals associated with the stereochemical activity of $\mathrm{Sb} 5 \mathrm{~s}^{2} \mathrm{LPEs}$ in (a) $\mathrm{Sb}_{2} \mathrm{~S}_{3}$, 
(b) $\mathrm{Sb}_{2}\left(\mathrm{~S}_{2} \mathrm{Se}\right)_{3}$, and (c) $\mathrm{Sb}_{2} \mathrm{Se}_{3}$. $\mathrm{Sb}$ atoms are shown as purple spheres, $\mathrm{S}$ atoms are yellow, and Se atoms are orange. The red and green colours orbitals represent positive and negative wavefunction, respectively. The orbitals are drawn at an isosurface value of 0.02 .

Contours of the electron density isosurface are plotted on the ac plane.

Table 1 Summarized crystal data and details of the refinement parameters for all crystals in the $\mathrm{Sb}_{2} \mathrm{~S}_{3-\mathrm{x}} \mathrm{Se}_{\mathrm{x}}$ solid solution

Table 2 Atomic coordinates, site occupancy parameters, equivalent isotropic, and anisotropic temperature factors $\left(\AA^{2}\right)$

Table 3 Intra-ribbon and inter-ribbon distances $(\AA)$ in the $\mathrm{Sb}_{2} \mathrm{~S}_{3-\mathrm{x}} \mathrm{Se}_{\mathrm{x}}$ solid solution 

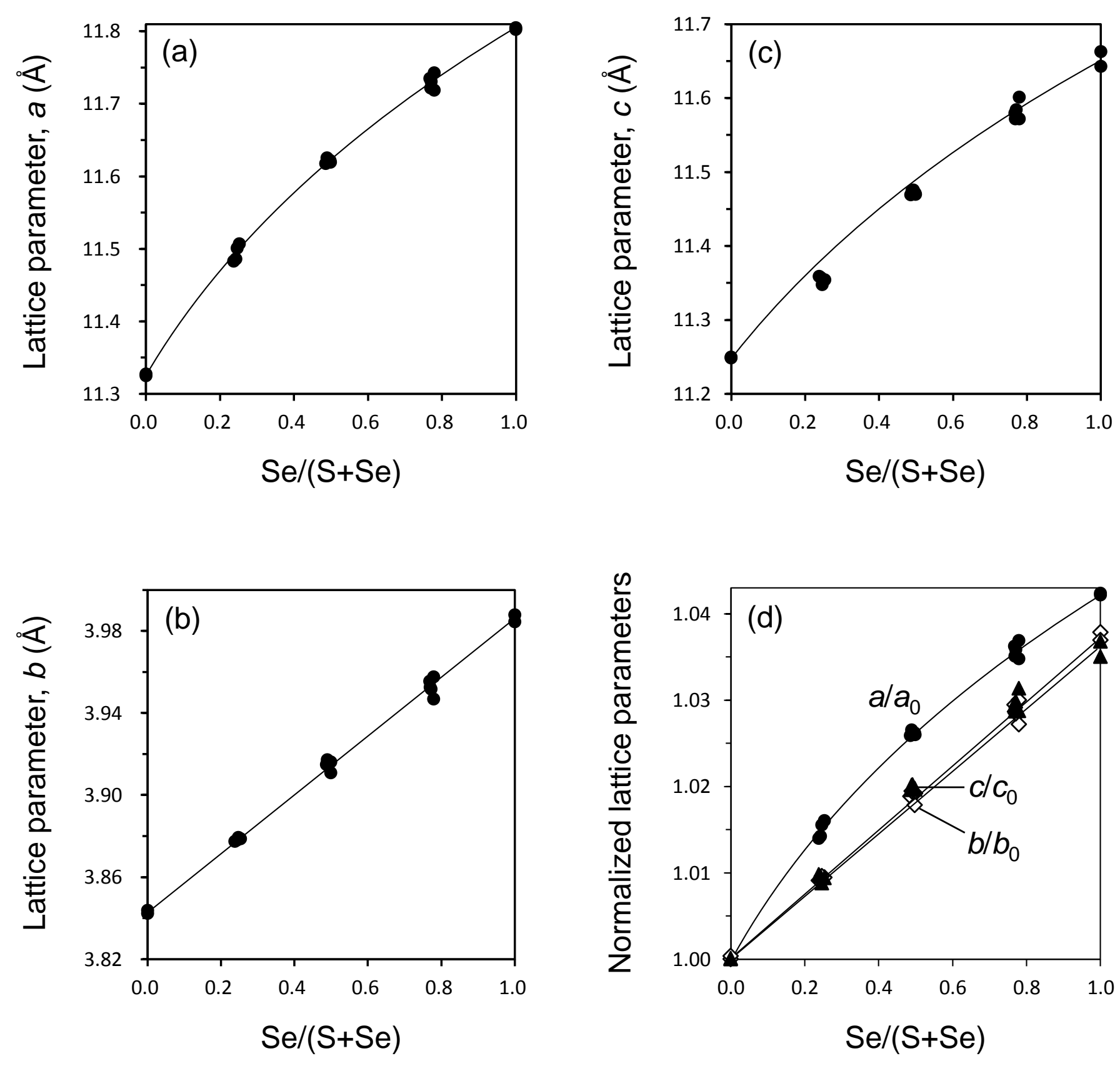

Figure 1. The compositional dependence lattice parameters of (a) $a$, (b) $b$, and (c) $c$. (d) The variations of normalized lattice parameters divided by minimum values for each lattice parameter. Solid circles, open diamonds, and solid triangles stand for the $a / a_{0}, b / b_{0}$, and $c / c_{0}$, respectively. Data were fitted by a least-squares regression to the second degree polynomial curve. The error bars are within the symbol size. 


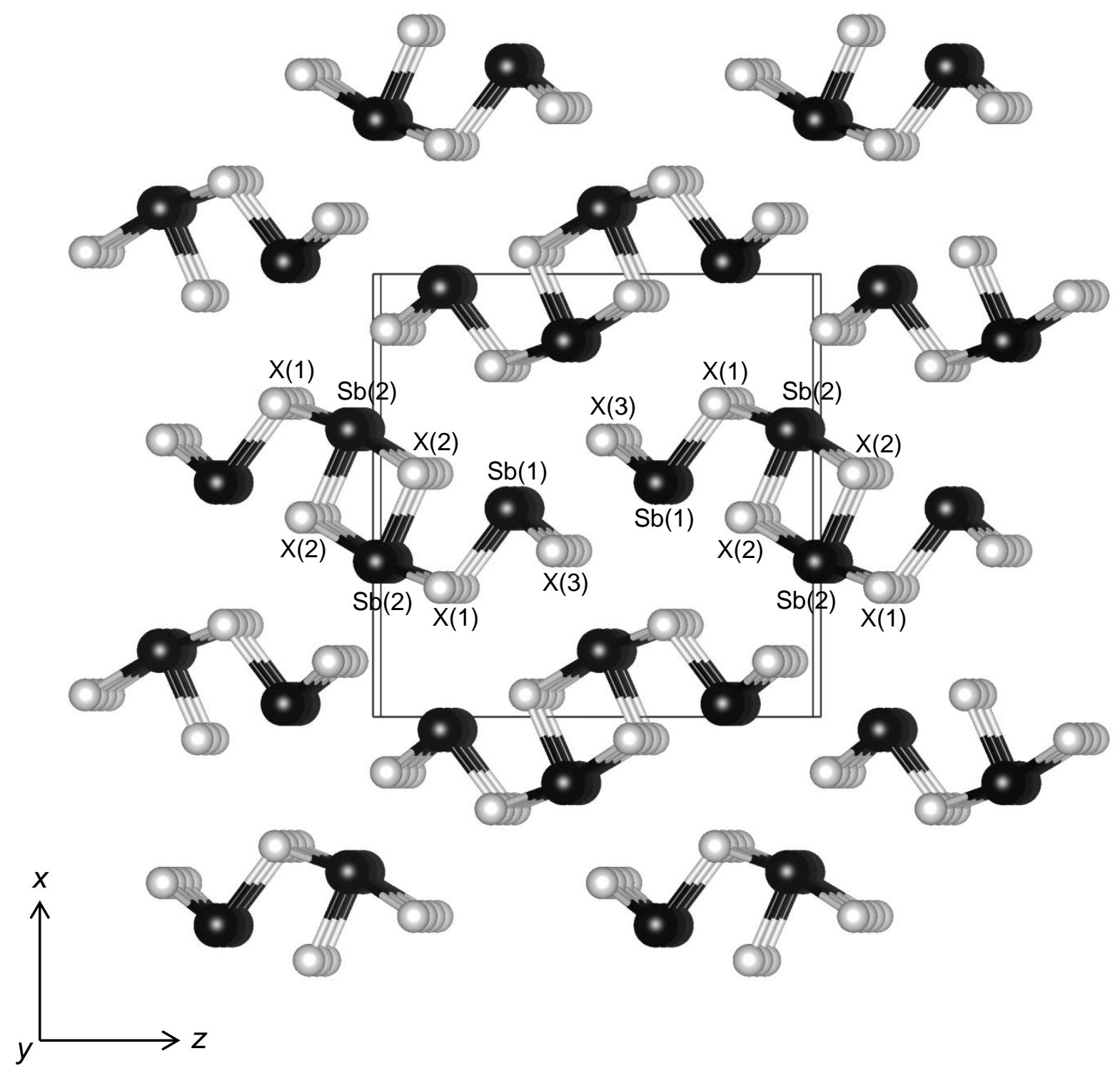

Figure 2. A ball-and-stick view of the crystal structure of $\mathrm{Sb}_{2} \mathrm{X}_{3}(\mathrm{X}=\mathrm{S}, \mathrm{Se})$ viewed in the direction of $b$-axis. 


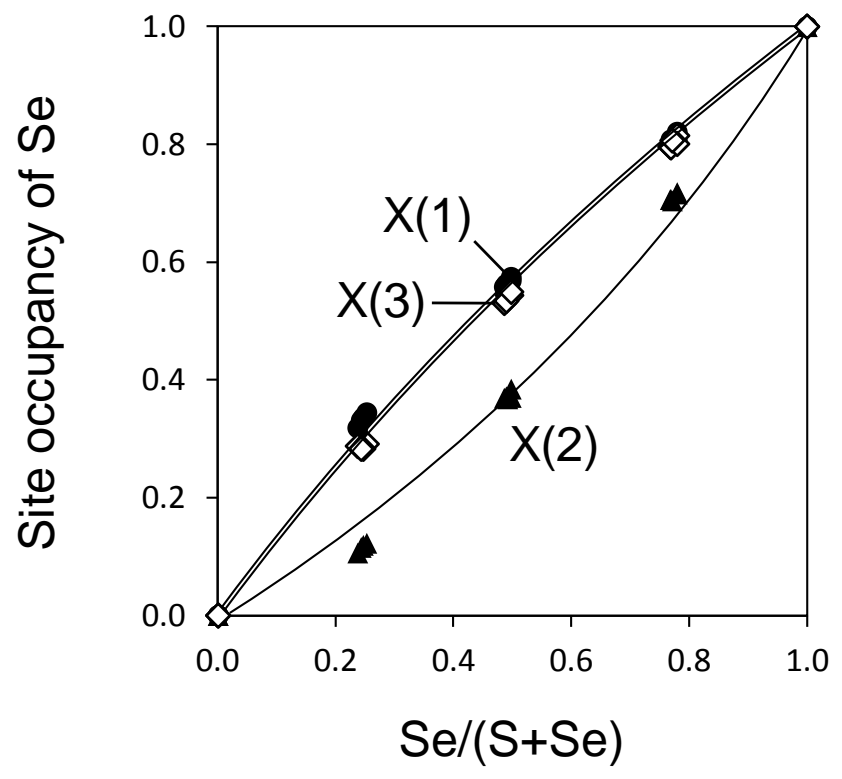

Figure 3. Site occupancy parameters of Se for the three $X$ sites $(X=S, S e)$ in the $\mathrm{Sb}_{2} \mathrm{~S}_{3-\mathrm{x}} \mathrm{Se}_{\mathrm{x}}$ solid solution. Solid circles, solid triangles, and open diamonds indicate the $X(1), X(2)$, and $X(3)$ site, respectively. 

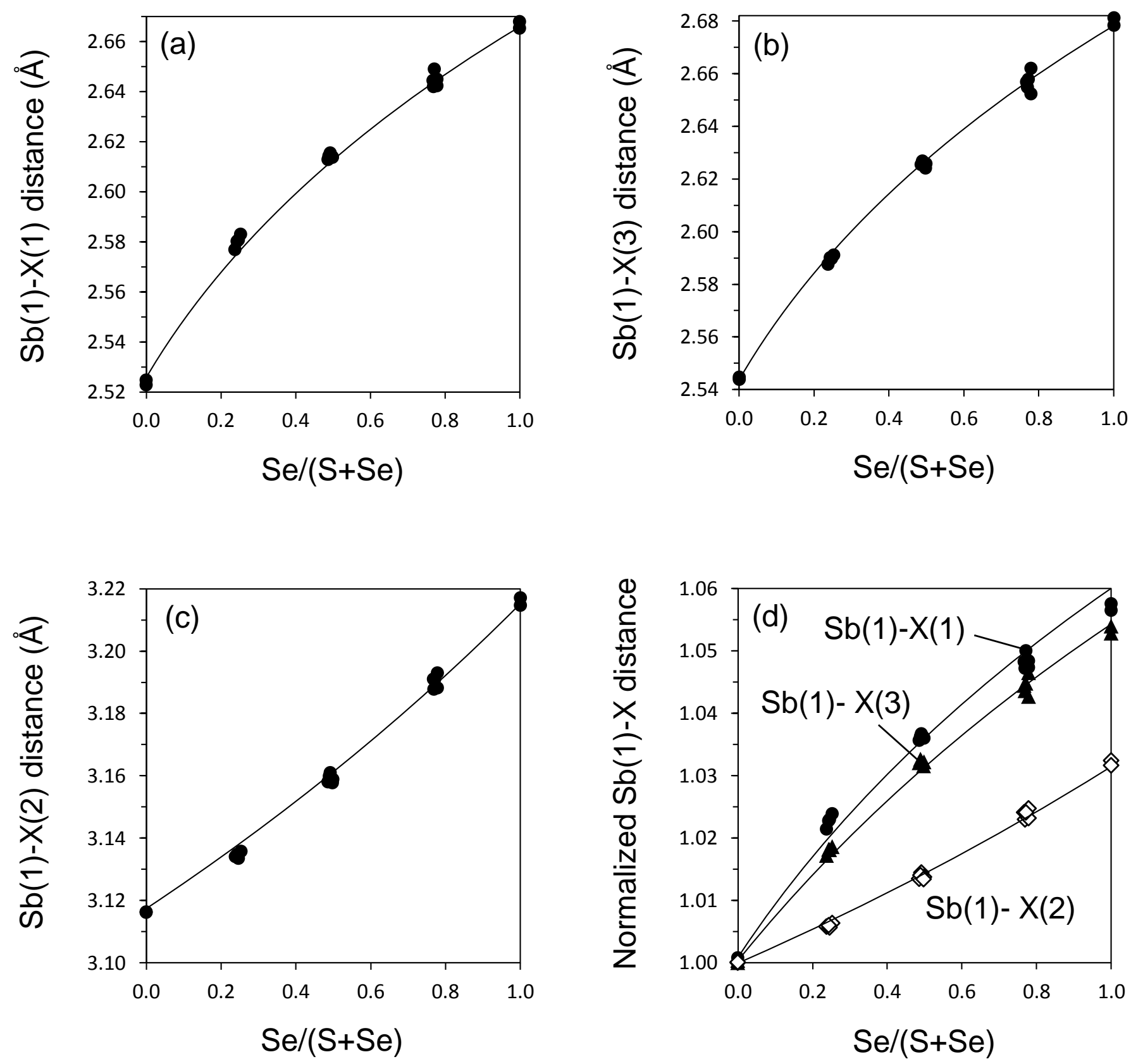

Figure 4. Variations of intra-ribbon $\mathrm{Sb}(1)-\mathrm{X}(\mathrm{X}=\mathrm{S}, \mathrm{Se})$ distances. (d) The variations of normalized $\mathrm{Sb}(1)-X$ distance. Solid circles, open diamonds, and solid triangles stand for the $\mathrm{Sb}(1)-\mathrm{X}(1), \mathrm{Sb}(1)-\mathrm{X}(2)$, and $\mathrm{Sb}(1)-\mathrm{X}(3)$, respectively. The error bars are smaller than the symbol size. 

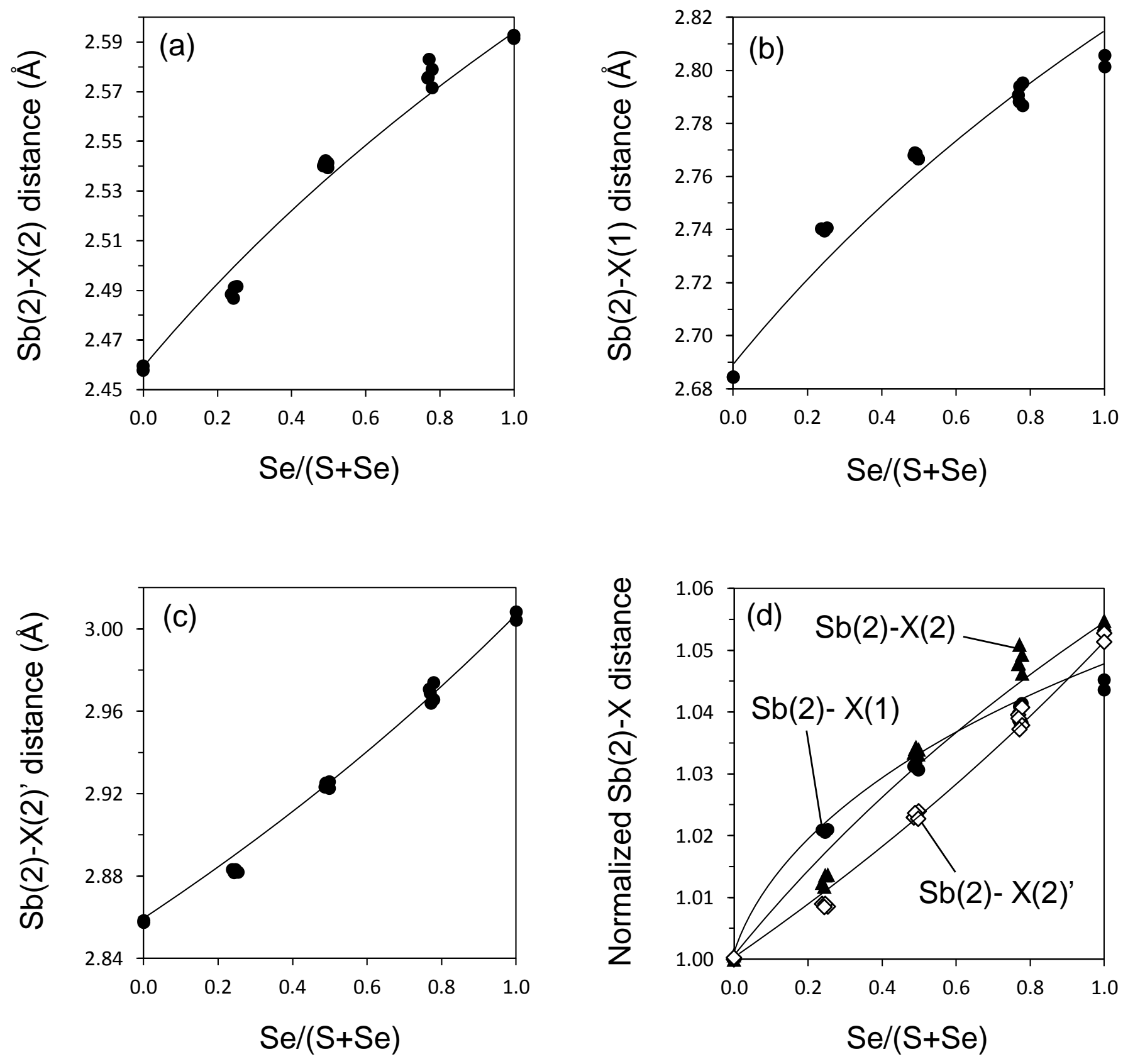

Figure 5. Variations of intra-ribbon $\mathrm{Sb}(2)-\mathrm{X}(\mathrm{X}=\mathrm{S}, \mathrm{Se})$ distances. (d) The variations of normalized $\mathrm{Sb}(2)-X$ distance. Solid circles, open diamonds, and solid triangles display the $\mathrm{Sb}(2)-\mathrm{X}(1), \mathrm{Sb}(2)-\mathrm{X}(2)$ ', and $\mathrm{Sb}(2)-\mathrm{X}(2)$, respectively. 

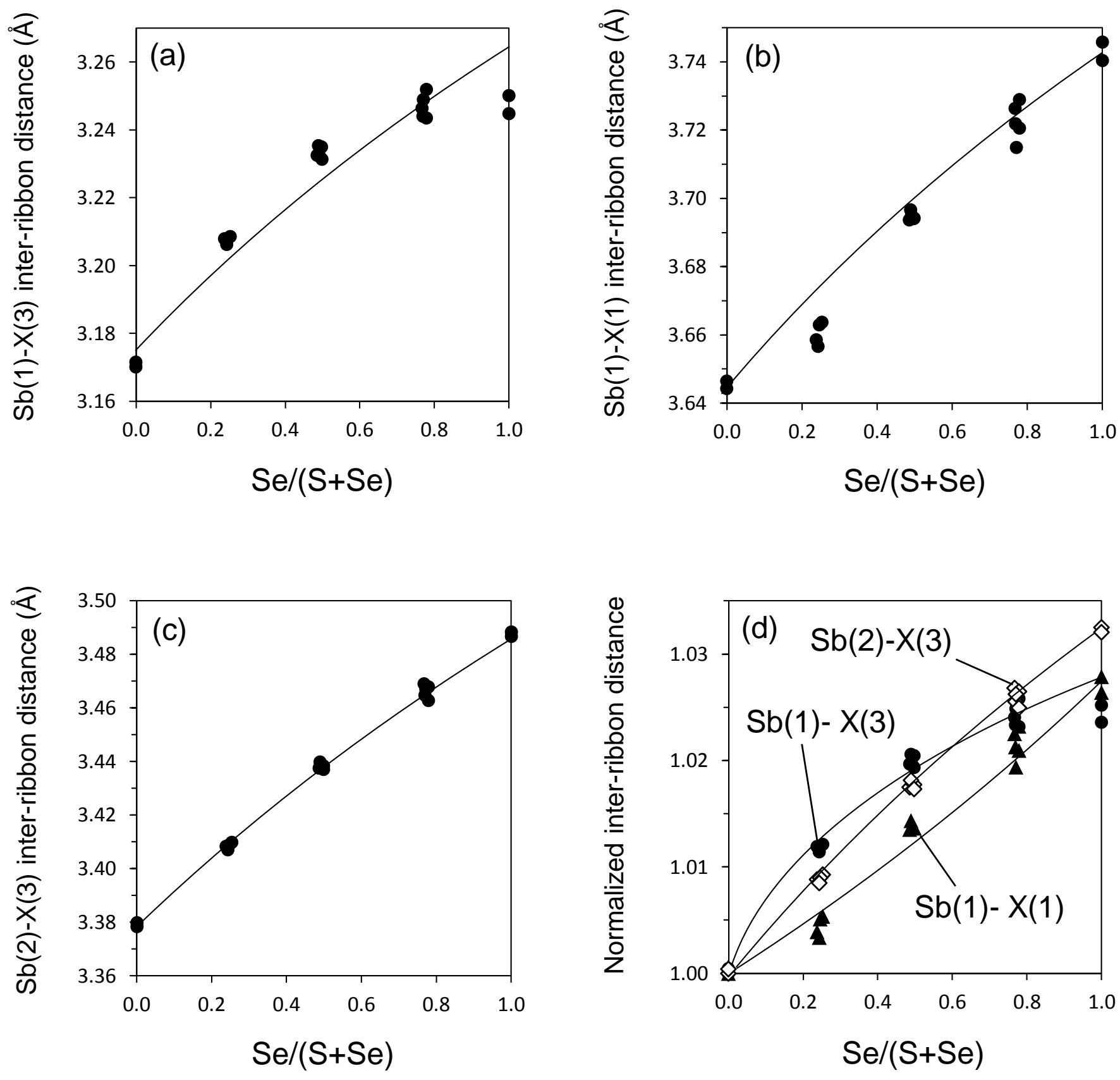

Figure 6. Variations of the inter-ribbon distances of $\mathrm{Sb}-\mathrm{X}(\mathrm{X}=\mathrm{S}, \mathrm{Se})$. (d) The variations of normalized inter-ribbon distance. Solid circles, open diamonds, and solid triangles show the $\mathrm{Sb}(1)-\mathrm{X}(3), \mathrm{Sb}(2)-\mathrm{X}(3)$, and $\mathrm{Sb}(1)-\mathrm{X}(1)$, respectively. 

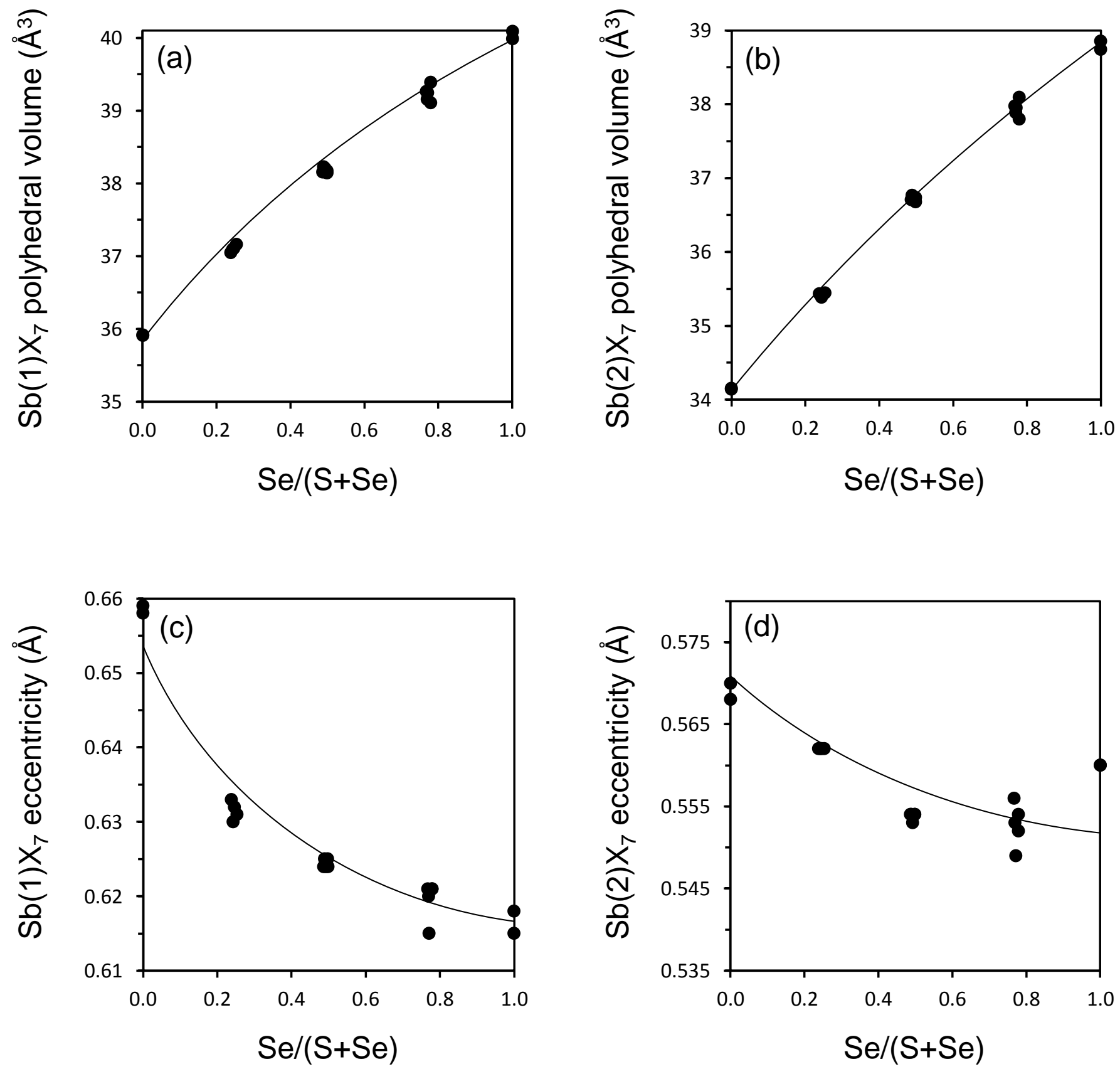

Figure 7. Variations of polyhedral volumes of $\mathrm{Sb}(1) \mathrm{X}_{7}$ and $\mathrm{Sb}(2) \mathrm{X}_{7}(\mathrm{X}=\mathrm{S}, \mathrm{Se})$ and their polyhedral eccentric parameters calculated by the IVTON program (Balić-Žunić and Vickovic 1996). 

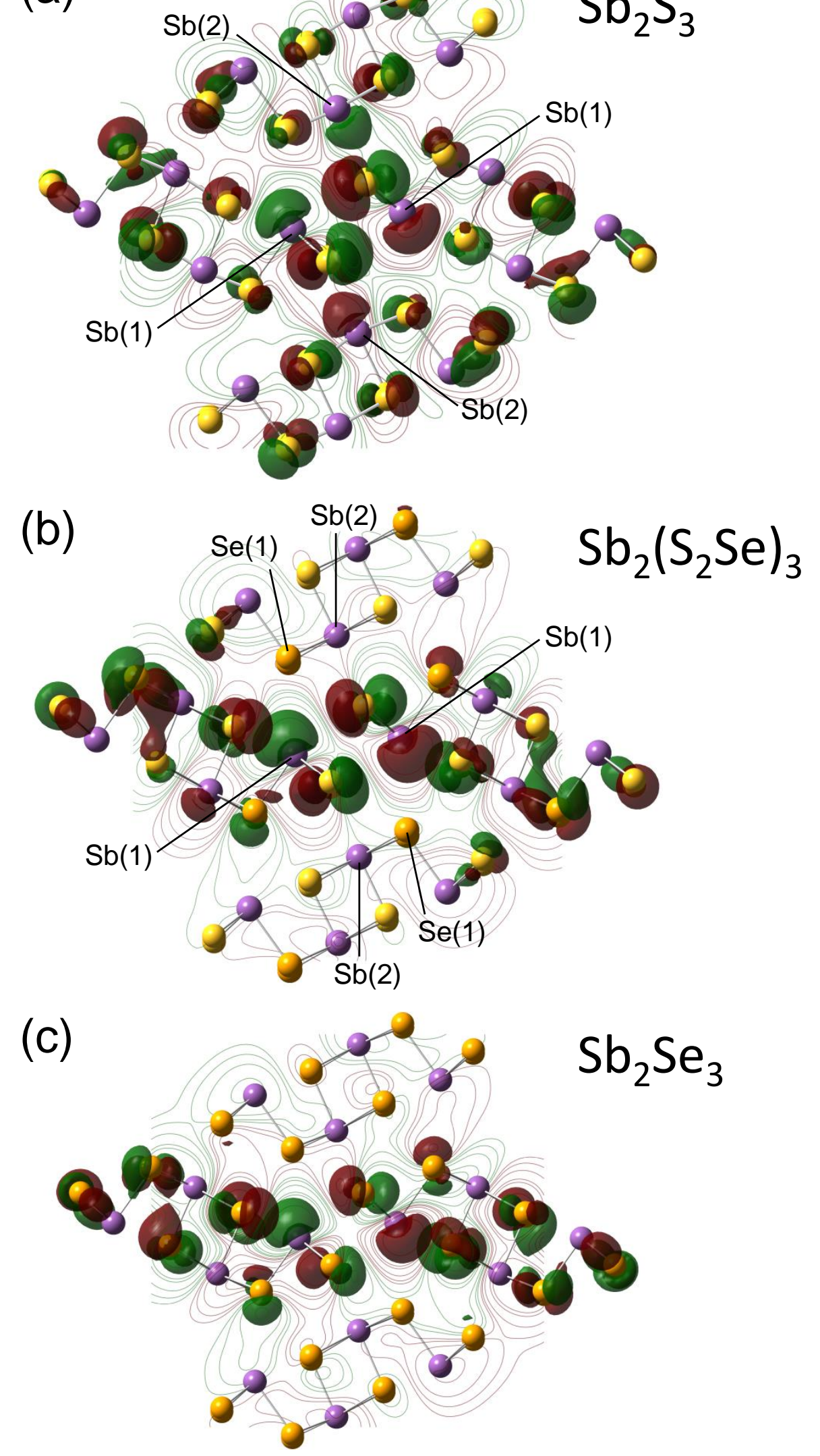

Figure 8. Molecular orbitals associated with the stereochemical activity of $\mathrm{Sb} 5 \mathrm{~s}^{2} \mathrm{LPEs}$ in (a) $\mathrm{Sb}_{2} \mathrm{~S}_{3}$, (b) $\mathrm{Sb}_{2}\left(\mathrm{~S}_{2} \mathrm{Se}\right)_{3}$, and (c) $\mathrm{Sb}_{2} \mathrm{Se}_{3}$. Sb atoms are shown as purple spheres, $\mathrm{S}$ atoms are yellow, and $\mathrm{Se}$ atoms are orange. The red and green colours orbitals represent positive and negative wavefunction, respectively. The orbitals are drawn at an isosurface value of 0.02 . Contours of the electron density isosurface are plotted on the ac plane. 
Table 1. Summarized crystal data and details of the refinement parameters for all crystals in the $\mathrm{Sb}_{2} \mathrm{~S}_{3-\mathrm{x}} \mathrm{Se}_{\mathrm{x}}$ solid solution

\begin{tabular}{|c|c|c|c|c|c|}
\hline Sample\# & S300Se0-1 & S300Se0-2 & S225Se075-1 & S225Se075-5 & S225Se075-6 \\
\hline Chemical composition & $\mathrm{Sb}_{2} \mathrm{~S}_{3}$ & $\mathrm{Sb}_{2} \mathrm{~S}_{3}$ & $\mathrm{Sb}_{2} \mathrm{~S}_{2.29} \mathrm{Se}_{0.71}$ & $\mathrm{Sb}_{2} \mathrm{~S}_{2.24} \mathrm{Se}_{0.76}$ & $\mathrm{Sb}_{2} \mathrm{~S}_{2.26} \mathrm{Se}_{0.74}$ \\
\hline Crystal size $(\mu \mathrm{m})$ & $300 \times 100 \times 100$ & $300 \times 150 \times 150$ & $300 \times 150 \times 150$ & $200 \times 100 \times 100$ & $300 \times 100 \times 100$ \\
\hline Crystal system & Orthorhombic & Orthorhombic & Orthorhombic & Orthorhombic & Orthorhombic \\
\hline Space group & Pnma & Pnma & Pnma & Pnma & Pnma \\
\hline Z & 4 & 4 & 4 & 4 & 4 \\
\hline$a(\AA)$ & $11.3276(17)$ & $11.3252(18)$ & $11.4834(11)$ & $11.5070(10)$ & $11.5011(9)$ \\
\hline$b(\AA)$ & $3.8423(6)$ & $3.8437(4)$ & $3.8773(3)$ & $3.8787(3)$ & $3.8792(2)$ \\
\hline$c(\AA)$ & $11.2484(18)$ & $11.2498(17)$ & $11.3589(8)$ & $11.3543(9)$ & $11.3475(9)$ \\
\hline$V\left(\AA^{3}\right)$ & $489.57(13)$ & $489.71(12)$ & $505.75(7)$ & $506.77(7)$ & $506.27(6)$ \\
\hline$D_{\text {calc }}\left(g / \mathrm{cm}^{3}\right)$ & 4.608 & 4.607 & 4.898 & 4.919 & 4.911 \\
\hline$\mu\left(\mathrm{cm}^{-1}\right)$ & 121.055 & 121.021 & 165.363 & 168.419 & 167.227 \\
\hline Total reflections, $R_{\mathrm{int}}$ & $4469,0.059$ & $4463,0.056$ & $4616,0.087$ & $4668,0.073$ & $4637,0.058$ \\
\hline Unique reflections & 640 & 639 & 657 & 659 & 658 \\
\hline Observed ref. with $F_{0}>4 \mathrm{~s}\left(F_{\mathrm{o}}\right)$ & 570 & 568 & 592 & 620 & 621 \\
\hline Paraeters & 32 & 32 & 44 & 44 & 44 \\
\hline$R 1$ & 0.0314 & 0.0341 & 0.0511 & 0.0406 & 0.0349 \\
\hline$w R 2$ & 0.0355 & 0.0413 & 0.0606 & 0.0472 & 0.0462 \\
\hline GooF & 1.047 & 1.046 & 1.061 & 1.038 & 1.038 \\
\hline Sample\# & S225Se075-7 & S150Se150-4 & S150Se150-5 & S150Se150-6 & S150Se150-7 \\
\hline Chemical composition & $\mathrm{Sb}_{2} \mathrm{~S}_{2.27} \mathrm{Se}_{0.73}$ & $\mathrm{Sb}_{2} \mathrm{~S}_{1.52} \mathrm{Se}_{1.48}$ & $\mathrm{Sb}_{2} \mathrm{~S}_{1.54} \mathrm{Se}_{1.46}$ & $\mathrm{Sb}_{2} \mathrm{~S}_{1.50} \mathrm{Se}_{1.50}$ & $\mathrm{Sb}_{2} \mathrm{~S}_{1.53} \mathrm{Se}_{1.47}$ \\
\hline Crystal size $(\mu \mathrm{m})$ & $300 \times 100 \times 100$ & $200 \times 50 \times 50$ & $200 \times 100 \times 100$ & $200 \times 100 \times 100$ & $200 \times 50 \times 50$ \\
\hline Crystal system & Orthorhombic & Orthorhombic & Orthorhombic & Orthorhombic & Orthorhombic \\
\hline Space group & Pnma & Pnma & Pnma & Pnma & Pnma \\
\hline Z & 4 & 4 & 4 & 4 & 4 \\
\hline$a(\AA)$ & $11.4862(10)$ & $11.6237(18)$ & $11.6182(10)$ & $11.6195(13)$ & $11.626(3)$ \\
\hline$b(\AA)$ & $3.8779(3)$ & $3.9153(4)$ & $3.9148(2)$ & $3.9161(3)$ & $3.9171(7)$ \\
\hline$c(\AA)$ & $11.3567(7)$ & $11.4756(15)$ & $11.4687(8)$ & $11.4696(10)$ & $11.475(2)$ \\
\hline$V\left(\AA^{3}\right)$ & $505.85(7)$ & $522.25(12)$ & $521.62(6)$ & $521.90(8)$ & $522.59(19)$ \\
\hline$D_{\text {calc }}\left(\mathrm{g} / \mathrm{cm}^{3}\right)$ & 4.909 & 5.203 & 5.197 & 5.218 & 5.193 \\
\hline$\mu\left(\mathrm{cm}^{-1}\right)$ & 166.687 & 210.739 & 209.678 & 212.199 & 209.945 \\
\hline Total reflections, $R_{\text {int }}$ & $4666,0.065$ & $4764,0.093$ & $4796,0.057$ & $4759,0.050$ & $4350,0.083$ \\
\hline Unique reflections & 657 & 678 & 679 & 679 & 673 \\
\hline Observed ref. with $F_{0}>4 \mathrm{~s}\left(F_{\mathrm{o}}\right)$ & 601 & 609 & 586 & 595 & 601 \\
\hline Parameters & 44 & 44 & 44 & 44 & 44 \\
\hline$R 1$ & 0.0389 & 0.0316 & 0.0297 & 0.0292 & 0.0505 \\
\hline$w R 2$ & 0.0470 & 0.0309 & 0.0342 & 0.0404 & 0.0537 \\
\hline GooF & 1.051 & 1.004 & 1.065 & 1.001 & 1.001 \\
\hline
\end{tabular}


Table 1. Continued

\begin{tabular}{|c|c|c|c|}
\hline Sample\# & S150Se150-8 & S075Se225-1 & S075Se225-2 \\
\hline Chemical composition & $\mathrm{Sb}_{2} \mathrm{~S}_{1.51} \mathrm{Se}_{1.49}$ & $\mathrm{Sb}_{2} \mathrm{~S}_{0.70} \mathrm{Se}_{2.30}$ & $\mathrm{Sb}_{2} \mathrm{~S}_{0.66} \mathrm{Se}_{2.34}$ \\
\hline Crystal size $(\mu \mathrm{m})$ & $300 \times 100 \times 100$ & $100 \times 50 \times 50$ & $200 \times 100 \times 100$ \\
\hline Crystal system & Orthorhombic & Orthorhombic & Orthorhombic \\
\hline Space group & Pnma & Pnma & Pnma \\
\hline Z & 4 & 4 & 4 \\
\hline$a(\AA)$ & $11.622(2)$ & $11.7354(17)$ & $11.743(3)$ \\
\hline$b(\AA)$ & $3.9108(6)$ & $3.9554(4)$ & $3.9576(11)$ \\
\hline$c(\AA)$ & $11.4712(14)$ & $11.5794(13)$ & $11.601(4)$ \\
\hline$V\left(\AA^{3}\right)$ & $521.40(14)$ & $537.50(11)$ & $539.1(3)$ \\
\hline$D_{\text {calc }}\left(\mathrm{g} / \mathrm{cm}^{3}\right)$ & 5.217 & 5.530 & 5.537 \\
\hline$\mu\left(\mathrm{cm}^{-1}\right)$ & 211.744 & 257.121 & 258.901 \\
\hline Total reflections, $R_{\text {int }}$ & $4744,0.079$ & $4778,0.074$ & $4587,0.118$ \\
\hline Unique reflections & 677 & 699 & 702 \\
\hline Observed ref. with $F_{0}>4 \mathrm{~s}\left(F_{\mathrm{o}}\right)$ & 618 & 578 & 544 \\
\hline Parameters & 44 & 44 & 44 \\
\hline$R 1$ & 0.0445 & 0.0353 & 0.0526 \\
\hline$w R 2$ & 0.0529 & 0.0423 & 0.0647 \\
\hline GooF & 1.062 & 1.025 & 1.002 \\
\hline Sample\# & S075Se225-10 & S0Se300-1 & S0Se300-3 \\
\hline Chemical composition & $\mathrm{Sb}_{2} \mathrm{~S}_{0.69} \mathrm{Se}_{2.31}$ & $\mathrm{Sb}_{2} \mathrm{Se}_{3}$ & $\mathrm{Sb}_{2} \mathrm{Se}_{3}$ \\
\hline Crystal size $(\mu \mathrm{m})$ & $200 \times 50 \times 50$ & $200 \times 100 \times 100$ & $300 \times 150 \times 150$ \\
\hline Crystal system & Orthorhombic & Orthorhombic & Orthorhombic \\
\hline Space group & Pnma & Pnma & Pnma \\
\hline $\mathrm{Z}$ & 4 & 4 & 4 \\
\hline$a(\AA)$ & $11.731(5)$ & $11.805(2)$ & $11.8026(7)$ \\
\hline$b(\AA)$ & $3.9516(13)$ & $3.9877(6)$ & $3.9843(3)$ \\
\hline$c(\AA)$ & $11.584(4)$ & $11.6623(16)$ & $11.6425(11)$ \\
\hline$V\left(\AA^{3}\right)$ & $537.0(3)$ & $549.03(15)$ & $547.49(7)$ \\
\hline $\mathrm{D}_{\text {calc }}\left(\mathrm{g} / \mathrm{cm}^{3}\right)$ & 5.541 & 5.811 & 5.828 \\
\hline$\mu\left(\mathrm{cm}^{-1}\right)$ & 258.010 & 295.480 & 296.310 \\
\hline Total reflections, $R_{\text {int }}$ & $4817,0.190$ & $5069,0.128$ & $5062,0.113$ \\
\hline Unique reflections & 701 & 714 & 711 \\
\hline Observed ref. with $F_{0}>4 \mathrm{~s}\left(F_{\mathrm{o}}\right)$ & 558 & 578 & 645 \\
\hline Parameters & 44 & 32 & 32 \\
\hline$R 1$ & 0.0554 & 0.0575 & 0.0566 \\
\hline$w R 2$ & 0.0477 & 0.0676 & 0.0617 \\
\hline GooF & 1.023 & 1.001 & 1.063 \\
\hline
\end{tabular}


Table 2. Atomic coordinates, site occupancy parameters, equivalent isotropic, and anisotropic temperature factors $\left(\AA^{2}\right)$

\begin{tabular}{|c|c|c|c|c|c|c|c|c|c|c|c|}
\hline & $x$ & $y$ & $z$ & $B_{\text {eq }}$ & Site occupancy (S/Se) & $U_{11}$ & $U_{22}$ & $U_{33}$ & $U_{12}$ & $U_{13}$ & $U_{23}$ \\
\hline \multicolumn{12}{|c|}{ S300Se0-1 } \\
\hline \multicolumn{12}{|l|}{$\mathrm{Sb}_{2} \mathrm{~S}_{3}$} \\
\hline $\mathrm{Sb}(1)$ & $0.47075(3)$ & 0.25 & $0.32604(3)$ & $1.151(6)$ & & $0.01506(16)$ & $0.01162(16)$ & $0.01704(18)$ & 0 & $0.00156(13)$ & 0 \\
\hline $\mathrm{Sb}(2)$ & $0.35052(3)$ & 0.75 & $0.03605(3)$ & $1.472(6)$ & & $0.01396(16)$ & $0.01793(18)$ & $0.02405(19)$ & 0 & $-0.00447(14)$ & 0 \\
\hline $\mathrm{X}(1)$ & $0.29216(10)$ & 0.25 & $0.19204(11)$ & $1.14(2)$ & $1.000 / 0.000$ & $0.0141(5)$ & $0.0144(5)$ & $0.0146(5)$ & 0 & $-0.0004(4)$ & 0 \\
\hline$X(2)$ & $0.54976(10)$ & 0.75 & $0.12296(11)$ & $1.11(2)$ & $1.000 / 0.000$ & $0.0127(4)$ & $0.0129(5)$ & $0.0166(5)$ & 0 & $-0.0019(4)$ & 0 \\
\hline $\mathrm{X}(3)$ & $0.37500(10)$ & 0.75 & $0.43881(11)$ & $1.15(2)$ & $1.000 / 0.000$ & $0.0169(5)$ & $0.0125(5)$ & $0.0144(5)$ & 0 & $0.0024(4)$ & 0 \\
\hline \multicolumn{12}{|c|}{ S300Se0-2 } \\
\hline \multicolumn{12}{|c|}{$\mathrm{Sb}_{2} \mathrm{~S}_{3}$} \\
\hline $\mathrm{Sb}(1)$ & $0.47075(3)$ & 0.25 & $0.32603(3)$ & $1.523(7)$ & & $0.02117(19)$ & $0.01914(19)$ & $0.01756(19)$ & 0 & $0.00167(12)$ & 0 \\
\hline $\mathrm{Sb}(2)$ & $0.35053(3)$ & 0.75 & $0.03601(3)$ & $1.827(7)$ & & $0.01954(19)$ & $0.0255(2)$ & $0.0244(2)$ & 0 & $-0.00477(14)$ & 0 \\
\hline $\mathrm{X}(1)$ & $0.29205(11)$ & 0.25 & $0.19184(10)$ & $1.51(2)$ & $1.000 / 0.000$ & $0.0188(5)$ & $0.0227(6)$ & $0.0159(5)$ & 0 & $-0.0012(4)$ & 0 \\
\hline$X(2)$ & $0.54964(10)$ & 0.75 & $0.12295(11)$ & $1.48(2)$ & $1.000 / 0.000$ & $0.0201(5)$ & $0.0196(6)$ & $0.0165(6)$ & 0 & $-0.0010(4)$ & 0 \\
\hline X(3) & $0.37508(11)$ & 0.75 & $0.43861(11)$ & $1.51(2)$ & $1.000 / 0.000$ & $0.0241(6)$ & $0.0202(6)$ & $0.0132(5)$ & 0 & $0.0021(4)$ & 0 \\
\hline \multicolumn{12}{|c|}{ S225Se075-1 } \\
\hline \multicolumn{12}{|c|}{$\mathrm{Sb}_{2} \mathrm{~S}_{2.29} \mathrm{Se}_{0.71}$} \\
\hline $\mathrm{Sb}(1)$ & $0.47001(4)$ & 0.25 & $0.32571(3)$ & $1.630(10)$ & & $0.0231(2)$ & $0.0157(2)$ & $0.0231(2)$ & 0 & $0.00205(16)$ & 0 \\
\hline $\mathrm{Sb}(2)$ & $0.35222(4)$ & 0.75 & $0.03521(4)$ & $1.886(11)$ & & $0.0222(2)$ & $0.0207(3)$ & $0.0288(2)$ & 0 & $-0.00453(17)$ & 0 \\
\hline $\mathrm{X}(1)$ & $0.28808(10)$ & 0.25 & $0.19290(8)$ & $1.58(2)$ & $0.682(2) / 0.318(2)$ & $0.0233(6)$ & $0.0165(6)$ & $0.0202(5)$ & 0 & $-0.0034(4)$ & 0 \\
\hline$X(2)$ & $0.55006(13)$ & 0.75 & $0.12460(11)$ & $1.55(3)$ & $0.894(2) / 0.106(2)$ & $0.0223(8)$ & $0.0151(8)$ & $0.0214(7)$ & 0 & $0.0017(5)$ & 0 \\
\hline X(3) & $0.37321(11)$ & 0.75 & $0.44055(10)$ & $1.71(2)$ & $0.712(2) / 0.288(2)$ & $0.0266(7)$ & $0.0183(7)$ & $0.0200(6)$ & 0 & $0.0027(4)$ & 0 \\
\hline \multicolumn{12}{|c|}{ S225Se075-5 } \\
\hline \multicolumn{12}{|c|}{$\mathrm{Sb}_{2} \mathrm{~S}_{2.24} \mathrm{Se}_{0.76}$} \\
\hline $\mathrm{Sb}(1)$ & $0.47008(2)$ & 0.25 & $0.32573(2)$ & $1.385(6)$ & & $0.01584(16)$ & $0.01752(17)$ & $0.01925(18)$ & 0 & $0.00212(10)$ & 0 \\
\hline $\mathrm{Sb}(2)$ & $0.35225(2)$ & 0.75 & $0.03511(3)$ & $1.648(7)$ & & $0.01467(17)$ & $0.02261(19)$ & $0.02535(19)$ & 0 & $-0.00493(11)$ & 0 \\
\hline $\mathrm{X}(1)$ & $0.28796(6)$ & 0.25 & $0.19272(6)$ & $1.425(15)$ & $0.656(1) / 0.344(1)$ & $0.0183(3)$ & $0.0196(4)$ & $0.0163(3)$ & 0 & $-0.0026(2)$ & 0 \\
\hline$X(2)$ & $0.55004(7)$ & 0.75 & $0.12441(9)$ & $1.473(19)$ & $0.877(1) / 0.123(1)$ & $0.0171(4)$ & $0.0190(5)$ & $0.0199(5)$ & 0 & $0.0012(3)$ & 0 \\
\hline $\mathrm{X}(3)$ & $0.37296(6)$ & 0.75 & $0.44070(7)$ & $1.343(15)$ & $0.708(1) / 0.292(1)$ & $0.0175(3)$ & $0.0180(4)$ & $0.0155(4)$ & 0 & $0.0021(2)$ & 0 \\
\hline \multicolumn{12}{|c|}{ S225Se075-6 } \\
\hline \multicolumn{12}{|c|}{$\mathrm{Sb}_{2} \mathrm{~S}_{2.26} \mathrm{Se}_{0.74}$} \\
\hline $\mathrm{Sb}(1)$ & $0.47001(2)$ & 0.25 & $0.32572(2)$ & $1.419(5)$ & & $0.01758(14)$ & $0.01546(15)$ & $0.02087(16)$ & 0 & $0.00198(8)$ & 0 \\
\hline $\mathrm{Sb}(2)$ & $0.35219(2)$ & 0.75 & $0.03515(2)$ & $1.687(6)$ & & $0.01655(14)$ & $0.02052(16)$ & $0.02701(16)$ & 0 & $-0.00509(8)$ & 0 \\
\hline $\mathrm{X}(1)$ & $0.28798(5)$ & 0.25 & $0.19273(5)$ & $1.444(11)$ & $0.664(1) / 0.336(1)$ & $0.0190(2)$ & $0.0178(3)$ & $0.0181(2)$ & 0 & $-0.0030(2)$ & 0 \\
\hline$X(2)$ & $0.55002(6)$ & 0.75 & $0.12457(7)$ & $1.465(14)$ & $0.881(1) / 0.119(1)$ & $0.0180(3)$ & $0.0162(4)$ & $0.0215(3)$ & 0 & $0.0009(2)$ & 0 \\
\hline$X(3)$ & $0.37298(5)$ & 0.75 & $0.44062(5)$ & $1.396(11)$ & $0.716(1) / 0.284(1)$ & $0.0194(2)$ & $0.0162(3)$ & $0.0175(3)$ & 0 & $0.0021(2)$ & 0 \\
\hline
\end{tabular}




\begin{tabular}{|c|c|c|c|c|c|c|c|c|c|c|c|}
\hline & $x$ & $y$ & $z$ & $B_{\text {eq }}$ & Site occupancy (S/Se) & $U_{11}$ & $U_{22}$ & $U_{33}$ & $U_{12}$ & $U_{13}$ & $U_{23}$ \\
\hline \multicolumn{12}{|c|}{ S225Se075-7 } \\
\hline \multicolumn{12}{|c|}{$\mathrm{Sb}_{2} \mathrm{~S}_{2.27} \mathrm{Se}_{0.73}$} \\
\hline $\operatorname{Sb}(1)$ & $0.47009(3)$ & 0.25 & $0.32568(3)$ & $1.489(7)$ & & $0.02071(19)$ & $0.01294(17)$ & $0.02291(19)$ & 0 & $0.00194(12)$ & 0 \\
\hline $\mathrm{Sb}(2)$ & $0.35224(3)$ & 0.75 & $0.03516(3)$ & $1.753(7)$ & & $0.01990(19)$ & $0.01779(19)$ & $0.02890(19)$ & 0 & $-0.00488(13)$ & 0 \\
\hline $\mathrm{X}(1)$ & $0.28793(7)$ & 0.25 & $0.19272(6)$ & $1.483(17)$ & $0.669(1) / 0.331(1)$ & $0.0226(4)$ & $0.0142(4)$ & $0.0196(4)$ & 0 & $-0.0029(2)$ & 0 \\
\hline$X(2)$ & $0.54996(9)$ & 0.75 & $0.12440(9)$ & $1.51(2)$ & $0.884(2) / 0.116(1)$ & $0.0214(5)$ & $0.0129(5)$ & $0.0232(5)$ & 0 & $0.0015(3)$ & 0 \\
\hline$X(3)$ & $0.37309(8)$ & 0.75 & $0.44076(7)$ & $1.478(18)$ & $0.717(1) / 0.283(1)$ & $0.0224(4)$ & $0.0139(4)$ & $0.0199(4)$ & 0 & $0.0020(2)$ & 0 \\
\hline \multicolumn{12}{|c|}{ S150Se150-4 } \\
\hline \multicolumn{12}{|c|}{$\mathrm{Sb}_{2} \mathrm{~S}_{1.52} \mathrm{Se}_{1.48}$} \\
\hline $\operatorname{Sb}(1)$ & $0.46970(5)$ & 0.25 & $0.32629(6)$ & $1.588(11)$ & & $0.0207(2)$ & $0.0178(2)$ & $0.0218(3)$ & 0 & $0.0020(2)$ & 0 \\
\hline $\mathrm{Sb}(2)$ & $0.35290(5)$ & 0.75 & $0.03625(5)$ & $1.857(12)$ & & $0.0200(2)$ & $0.0225(3)$ & $0.0281(3)$ & 0 & $-0.0055(2)$ & 0 \\
\hline$X(1)$ & $0.28700(9)$ & 0.25 & $0.19325(10)$ & $1.43(2)$ & $0.436(2) / 0.564(2)$ & $0.0201(6)$ & $0.0171(6)$ & $0.0171(6)$ & 0 & $-0.0013(4)$ & 0 \\
\hline$X(2)$ & $0.55245(11)$ & 0.75 & $0.12691(11)$ & $1.51(2)$ & $0.632(2) / 0.368(2)$ & $0.0206(7)$ & $0.0158(6)$ & $0.0208(8)$ & 0 & $0.0017(5)$ & 0 \\
\hline $\mathrm{X}(3)$ & $0.37184(9)$ & 0.75 & $0.44224(10)$ & $1.44(2)$ & $0.456(2) / 0.544(2)$ & $0.0213(6)$ & $0.0172(5)$ & $0.0160(6)$ & 0 & $0.0016(4)$ & 0 \\
\hline \multicolumn{12}{|c|}{ S150Se150-5 } \\
\hline \multicolumn{12}{|c|}{$\mathrm{Sb}_{2} \mathrm{~S}_{1.54} \mathrm{Se}_{1.46}$} \\
\hline $\mathrm{Sb}(1)$ & $0.46960(3)$ & 0.25 & $0.32614(3)$ & $1.534(6)$ & & $0.01950(18)$ & $0.01653(17)$ & $0.02227(17)$ & 0 & $0.00213(13)$ & 0 \\
\hline $\mathrm{Sb}(2)$ & $0.35294(3)$ & 0.75 & $0.03622(3)$ & $1.807(7)$ & & $0.01863(19)$ & $0.0214(2)$ & $0.02861(19)$ & 0 & $-0.00564(14)$ & 0 \\
\hline $\mathrm{X}(1)$ & $0.28695(6)$ & 0.25 & $0.19323(6)$ & $1.384(14)$ & $0.443(1) / 0.557(1)$ & $0.0186(3)$ & $0.0170(3)$ & $0.0170(3)$ & 0 & $-0.0019(2)$ & 0 \\
\hline$X(2)$ & $0.55237(7)$ & 0.75 & $0.12698(7)$ & $1.484(17)$ & $0.631(1) / 0.369(1)$ & $0.0207(4)$ & $0.0150(4)$ & $0.0207(4)$ & 0 & $0.0018(2)$ & 0 \\
\hline$X(3)$ & $0.37188(6)$ & 0.75 & $0.44223(6)$ & $1.322(15)$ & $0.467(1) / 0.533(1)$ & 0.0185(3) & $0.0148(3)$ & $0.0169(3)$ & 0 & $0.0020(2)$ & 0 \\
\hline \multicolumn{12}{|c|}{ S150Se150-6 } \\
\hline \multicolumn{12}{|c|}{$\mathrm{Sb}_{2} \mathrm{~S}_{1.50} \mathrm{Se}_{1.50}$} \\
\hline $\operatorname{Sb}(1)$ & $0.46963(4)$ & 0.25 & $0.32624(4)$ & $1.622(8)$ & & $0.0222(2)$ & $0.01807(19)$ & $0.0214(2)$ & 0 & $0.00187(16)$ & 0 \\
\hline $\mathrm{Sb}(2)$ & $0.35290(4)$ & 0.75 & $0.03645(4)$ & $1.909(8)$ & & $0.0214(2)$ & $0.0227(2)$ & $0.0285(2)$ & 0 & $-0.00547(18)$ & 0 \\
\hline $\mathrm{X}(1)$ & $0.28698(7)$ & 0.25 & $0.19323(7)$ & $1.525(17)$ & $0.432(2) / 0.568(2)$ & $0.0225(4)$ & $0.0188(4)$ & $0.0167(4)$ & 0 & $-0.0019(3)$ & 0 \\
\hline$X(2)$ & $0.55248(8)$ & 0.75 & $0.12708(8)$ & $1.61(2)$ & $0.616(2) / 0.384(2)$ & $0.0237(5)$ & $0.0171(4)$ & $0.0205(5)$ & 0 & $0.0028(3)$ & 0 \\
\hline$X(3)$ & $0.37187(7)$ & 0.75 & $0.44226(7)$ & $1.465(17)$ & $0.456(2) / 0.544(2)$ & $0.0220(4)$ & $0.0176(4)$ & $0.0160(4)$ & 0 & $0.0019(3)$ & 0 \\
\hline \multicolumn{12}{|c|}{ S150Se150-7 } \\
\hline \multicolumn{12}{|c|}{$\mathrm{Sb}_{2} \mathrm{~S}_{1.53} \mathrm{Se}_{1.47}$} \\
\hline $\operatorname{Sb}(1)$ & $0.46959(3)$ & 0.25 & $0.32612(4)$ & $1.484(9)$ & & $0.0191(2)$ & $0.0170(2)$ & $0.0203(2)$ & 0 & $0.00195(15)$ & 0 \\
\hline $\mathrm{Sb}(2)$ & $0.35293(4)$ & 0.75 & $0.03625(5)$ & $1.761(9)$ & & $0.0188(2)$ & $0.0216(2)$ & $0.0265(2)$ & 0 & $-0.00546(17)$ & 0 \\
\hline $\mathrm{X}(1)$ & $0.28698(7)$ & 0.25 & $0.19318(8)$ & $1.390(18)$ & $0.438(2) / 0.562(2)$ & $0.0185(4)$ & $0.0186(4)$ & $0.0157(4)$ & 0 & $-0.0021(2)$ & 0 \\
\hline$X(2)$ & $0.55237(8)$ & 0.75 & $0.12697(9)$ & $1.45(2)$ & $0.628(2) / 0.372(2)$ & $0.0190(5)$ & $0.0163(5)$ & $0.0199(6)$ & 0 & $0.0015(3)$ & 0 \\
\hline$X(3)$ & $0.37185(7)$ & 0.75 & $0.44217(9)$ & $1.311(18)$ & $0.466(2) / 0.534(2)$ & $0.0191(4)$ & $0.0164(4)$ & $0.0143(5)$ & 0 & $0.0021(2)$ & 0 \\
\hline
\end{tabular}




\begin{tabular}{|c|c|c|c|c|c|c|c|c|c|c|c|}
\hline & $x$ & $y$ & $z$ & $B_{\text {eq }}$ & Site occupancy (S/Se) & $U_{11}$ & $U_{22}$ & $U_{33}$ & $U_{12}$ & $U_{13}$ & $U_{23}$ \\
\hline \multicolumn{12}{|c|}{ S150Se150-8 } \\
\hline \multicolumn{12}{|c|}{$\mathrm{Sb}_{2} \mathrm{~S}_{1.51} \mathrm{Se}_{1.49}$} \\
\hline $\mathrm{Sb}(1)$ & $0.46956(4)$ & 0.25 & $0.32611(4)$ & $1.357(9)$ & & $0.0188(2)$ & $0.0140(2)$ & $0.0187(2)$ & 0 & $0.00188(15)$ & 0 \\
\hline $\mathrm{Sb}(2)$ & $0.35293(4)$ & 0.75 & $0.03633(4)$ & $1.629(10)$ & & $0.0186(2)$ & $0.0185(2)$ & $0.0248(2)$ & 0 & $-0.00526(17)$ & 0 \\
\hline $\mathrm{X}(1)$ & $0.28683(7)$ & 0.25 & $0.19325(7)$ & $1.254(18)$ & $0.426(2) / 0.574(2)$ & $0.0184(4)$ & $0.0141(4)$ & $0.0152(4)$ & 0 & $-0.0027(2)$ & 0 \\
\hline$X(2)$ & $0.55231(9)$ & 0.75 & $0.12688(8)$ & $1.30(2)$ & $0.630(2) / 0.370(2)$ & $0.0198(6)$ & $0.0116(5)$ & $0.0178(6)$ & 0 & $0.0014(3)$ & 0 \\
\hline $\mathrm{X}(3)$ & $0.37180(7)$ & 0.75 & $0.44217(8)$ & $1.164(19)$ & $0.450(2) / 0.550(2)$ & $0.0182(5)$ & $0.0129(4)$ & $0.0132(4)$ & 0 & $0.0014(2)$ & 0 \\
\hline \multicolumn{12}{|c|}{ S075Se225-1 } \\
\hline \multicolumn{12}{|c|}{$\mathrm{Sb}_{2} \mathrm{~S}_{0.70} \mathrm{Se}_{2.30}$} \\
\hline $\mathrm{Sb}(1)$ & $0.46948(4)$ & 0.25 & $0.32711(4)$ & $1.570(9)$ & & $0.0231(2)$ & $0.0164(2)$ & $0.0201(2)$ & 0 & $0.00228(19)$ & 0 \\
\hline $\mathrm{Sb}(2)$ & $0.35299(4)$ & 0.75 & $0.03802(5)$ & $1.821(10)$ & & $0.0215(2)$ & $0.0215(2)$ & $0.0262(2)$ & 0 & $-0.00481(19)$ & 0 \\
\hline$X(1)$ & $0.28633(7)$ & 0.25 & $0.19405(7)$ & $1.447(17)$ & $0.202(2) / 0.798(2)$ & $0.0215(4)$ & $0.0179(4)$ & $0.0155(4)$ & 0 & $-0.0015(3)$ & 0 \\
\hline$X(2)$ & $0.55355(7)$ & 0.75 & $0.12834(7)$ & $1.549(18)$ & $0.294(2) / 0.706(2)$ & $0.0231(5)$ & $0.0163(4)$ & $0.0194(4)$ & 0 & $0.0008(3)$ & 0 \\
\hline X(3) & $0.37129(6)$ & 0.75 & $0.44363(7)$ & $1.479(17)$ & $0.204(2) / 0.796(2)$ & $0.0234(5)$ & $0.0170(4)$ & $0.0158(4)$ & 0 & $0.0021(2)$ & 0 \\
\hline \multicolumn{12}{|c|}{ S075Se225-2 } \\
\hline \multicolumn{12}{|c|}{$\mathrm{Sb}_{2} \mathrm{~S}_{0.66} \mathrm{Se}_{2.34}$} \\
\hline $\mathrm{Sb}(1)$ & $0.46953(9)$ & 0.25 & $0.32699(10)$ & $1.82(2)$ & & $0.0239(5)$ & $0.0209(5)$ & $0.0243(5)$ & 0 & $0.0025(4)$ & 0 \\
\hline $\mathrm{Sb}(2)$ & $0.35287(9)$ & 0.75 & $0.03792(10)$ & $2.08(2)$ & & $0.0236(6)$ & $0.0251(5)$ & $0.0303(6)$ & 0 & $-0.0054(4)$ & 0 \\
\hline $\mathrm{X}(1)$ & $0.28639(15)$ & 0.25 & $0.19425(14)$ & $1.66(4)$ & $0.194(4) / 0.806(4)$ & $0.0222(11)$ & $0.0220(10)$ & $0.0188(9)$ & 0 & $-0.0010(6)$ & 0 \\
\hline$X(2)$ & $0.55354(15)$ & 0.75 & $0.12837(15)$ & $1.76(4)$ & $0.284(4) / 0.716(4)$ & $0.0241(12)$ & $0.0202(9)$ & $0.0224(10)$ & 0 & $0.0015(7)$ & 0 \\
\hline$X(3)$ & $0.37111(14)$ & 0.75 & $0.44379(15)$ & $1.80(4)$ & $0.186(4) / 0.814(4)$ & $0.0258(12)$ & $0.0226(8)$ & $0.0200(10)$ & 0 & $0.0030(6)$ & 0 \\
\hline \multicolumn{12}{|c|}{ S075Se225-3 } \\
\hline \multicolumn{12}{|c|}{$\mathrm{Sb}_{2} \mathrm{~S}_{0.69} \mathrm{Se}_{2.31}$} \\
\hline $\mathrm{Sb}(1)$ & $0.46949(4)$ & 0.25 & $0.32704(4)$ & $1.392(8)$ & & $0.0165(2)$ & $0.0161(2)$ & $0.0203(2)$ & 0 & $0.00235(18)$ & 0 \\
\hline $\mathrm{Sb}(2)$ & $0.35283(4)$ & 0.75 & $0.03796(4)$ & $1.664(9)$ & & $0.0155(2)$ & $0.0212(2)$ & $0.0266(2)$ & 0 & $-0.00468(19)$ & 0 \\
\hline $\mathrm{X}(1)$ & $0.28632(6)$ & 0.25 & $0.19400(6)$ & $1.313(16)$ & $0.192(2) / 0.808(2)$ & $0.0156(3)$ & $0.0180(4)$ & $0.0162(4)$ & 0 & $-0.0015(2)$ & 0 \\
\hline$X(2)$ & $0.55361(6)$ & 0.75 & $0.12840(7)$ & $1.369(17)$ & $0.294(2) / 0.706(2)$ & $0.0169(4)$ & $0.0157(4)$ & $0.0194(4)$ & 0 & $0.0008(3)$ & 0 \\
\hline$X(3)$ & $0.37135(6)$ & 0.75 & $0.44361(7)$ & $1.283(16)$ & $0.206(2) / 0.794(2)$ & $0.0167(4)$ & $0.0161(3)$ & $0.0159(4)$ & 0 & $0.0017(2)$ & 0 \\
\hline \multicolumn{12}{|c|}{ S075Se225-9 } \\
\hline \multicolumn{12}{|c|}{$\mathrm{Sb}_{2} \mathrm{~S}_{0.66} \mathrm{Se}_{2.34}$} \\
\hline $\mathrm{Sb}(1)$ & $0.46947(4)$ & 0.25 & $0.32717(4)$ & $1.338(10)$ & & $0.0174(2)$ & $0.0135(2)$ & $0.0200(2)$ & 0 & $0.0022(2)$ & 0 \\
\hline $\mathrm{Sb}(2)$ & $0.35297(4)$ & 0.75 & $0.03802(5)$ & $1.584(10)$ & & $0.0164(2)$ & $0.0183(2)$ & $0.0255(2)$ & 0 & $-0.0047(2)$ & 0 \\
\hline $\mathrm{X}(1)$ & $0.28627(7)$ & 0.25 & $0.19406(7)$ & 1.301(18) & $0.180(2) / 0.820(2)$ & $0.0167(4)$ & $0.0164(5)$ & $0.0163(4)$ & 0 & $-0.0012(3)$ & 0 \\
\hline$X(2)$ & $0.55352(7)$ & 0.75 & $0.12822(7)$ & 1.321(19) & $0.282(2) / 0.712(2)$ & $0.0172(5)$ & $0.0140(4)$ & $0.0190(4)$ & 0 & $0.0007(3)$ & 0 \\
\hline$X(3)$ & $0.37121(7)$ & 0.75 & $0.44362(8)$ & $1.241(18)$ & $0.200(2) / 0.800(2)$ & $0.0170(4)$ & $0.0145(4)$ & $0.0157(4)$ & 0 & $0.0021(3)$ & 0 \\
\hline
\end{tabular}




\begin{tabular}{|c|c|c|c|c|c|c|c|c|c|c|c|}
\hline & $x$ & $y$ & $z$ & $B_{\mathrm{eq}}$ & Site occupancy (S/Se) & $U_{11}$ & $U_{22}$ & $U_{33}$ & $U_{12}$ & $U_{13}$ & $U_{23}$ \\
\hline \multicolumn{12}{|c|}{ S075Se225-10 } \\
\hline \multicolumn{12}{|c|}{$\mathrm{Sb}_{2} \mathrm{~S}_{0.69} \mathrm{Se}_{2.31}$} \\
\hline $\operatorname{Sb}(1)$ & $0.4696(2)$ & 0.25 & $0.32673(15)$ & $2.28(4)$ & & $0.0384(15)$ & $0.0224(9)$ & $0.0260(9)$ & 0 & $0.0037(10)$ & 0 \\
\hline $\mathrm{Sb}(2)$ & $0.3529(2)$ & 0.75 & $0.03776(15)$ & $2.36(4)$ & & $0.0326(15)$ & $0.0266(10)$ & $0.0305(11)$ & 0 & $-0.0054(10)$ & 0 \\
\hline $\mathrm{X}(1)$ & $0.2856(3)$ & 0.25 & $0.1941(2)$ & 2.34(9) & $0.196(8) / 0.804(8)$ & $0.039(2)$ & $0.028(2)$ & $0.0227(18)$ & 0 & $-0.0017(15)$ & 0 \\
\hline$X(2)$ & $0.5542(3)$ & 0.75 & $0.1281(2)$ & 2.33(9) & $0.296(7) / 0.704(7)$ & $0.038(3)$ & $0.0234(19)$ & $0.027(2)$ & 0 & $-0.0023(17)$ & 0 \\
\hline$X(3)$ & $0.3714(3)$ & 0.75 & $0.4436(2)$ & $2.21(8)$ & $0.194(7) / 0.806(7)$ & $0.036(2)$ & $0.0213(18)$ & $0.0263(19)$ & 0 & $0.0022(19)$ & 0 \\
\hline \multicolumn{12}{|c|}{ S0Se300-1 } \\
\hline \multicolumn{12}{|c|}{$\mathrm{Sb}_{2} \mathrm{Se}_{3}$} \\
\hline $\operatorname{Sb}(1)$ & $0.46976(9)$ & 0.25 & $0.32795(8)$ & $1.72(2)$ & & $0.0264(6)$ & $0.0150(5)$ & $0.0238(5)$ & 0 & $0.0020(4)$ & 0 \\
\hline $\mathrm{Sb}(2)$ & $0.35265(10)$ & 0.75 & $0.03946(9)$ & $1.89(2)$ & & $0.0243(6)$ & $0.0183(5)$ & $0.0291(6)$ & 0 & $-0.0027(4)$ & 0 \\
\hline$X(1)$ & $0.28627(13)$ & 0.25 & $0.19480(12)$ & $1.58(3)$ & $0.000 / 1.000$ & $0.0237(9)$ & $0.0161(8)$ & $0.0203(8)$ & 0 & $-0.0010(6)$ & 0 \\
\hline$X(2)$ & $0.55363(14)$ & 0.75 & $0.12881(12)$ & $1.58(3)$ & $0.000 / 1.000$ & $0.0248(9)$ & $0.0136(7)$ & $0.0218(8)$ & 0 & $0.0004(6)$ & 0 \\
\hline$X(3)$ & $0.37100(13)$ & 0.75 & $0.44472(13)$ & $1.56(3)$ & $0.000 / 1.000$ & $0.0267(9)$ & $0.0146(7)$ & $0.0177(8)$ & 0 & $0.0015(6)$ & 0 \\
\hline \multicolumn{12}{|c|}{ S0Se300-3 } \\
\hline \multicolumn{12}{|c|}{$\mathrm{Sb}_{2} \mathrm{Se}_{3}$} \\
\hline $\mathrm{Sb}(1)$ & $0.46987(4)$ & 0.25 & $0.32798(6)$ & $1.415(13)$ & & $0.0200(3)$ & $0.0107(3)$ & $0.0231(4)$ & 0 & 0.00187(19) & 0 \\
\hline $\mathrm{Sb}(2)$ & $0.35256(4)$ & 0.75 & $0.03955(6)$ & $1.657(14)$ & & $0.0179(3)$ & $0.0154(3)$ & $0.0297(4)$ & 0 & $-0.0037(2)$ & 0 \\
\hline$X(1)$ & $0.28600(6)$ & 0.25 & $0.19467(8)$ & $1.239(18)$ & $0.000 / 1.000$ & $0.0171(4)$ & $0.0120(4)$ & $0.0180(5)$ & 0 & $-0.0006(2)$ & 0 \\
\hline$X(2)$ & $0.55386(6)$ & 0.75 & $0.12871(8)$ & $1.255(17)$ & $0.000 / 1.000$ & $0.0174(3)$ & $0.0110(4)$ & $0.0193(5)$ & 0 & $-0.0005(2)$ & 0 \\
\hline$X(3)$ & $0.37109(6)$ & 0.75 & $0.44467(9)$ & $1.273(18)$ & $0.000 / 1.000$ & $0.0183(4)$ & $0.0113(4)$ & $0.0187(5)$ & 0 & $0.0021(2)$ & 0 \\
\hline
\end{tabular}




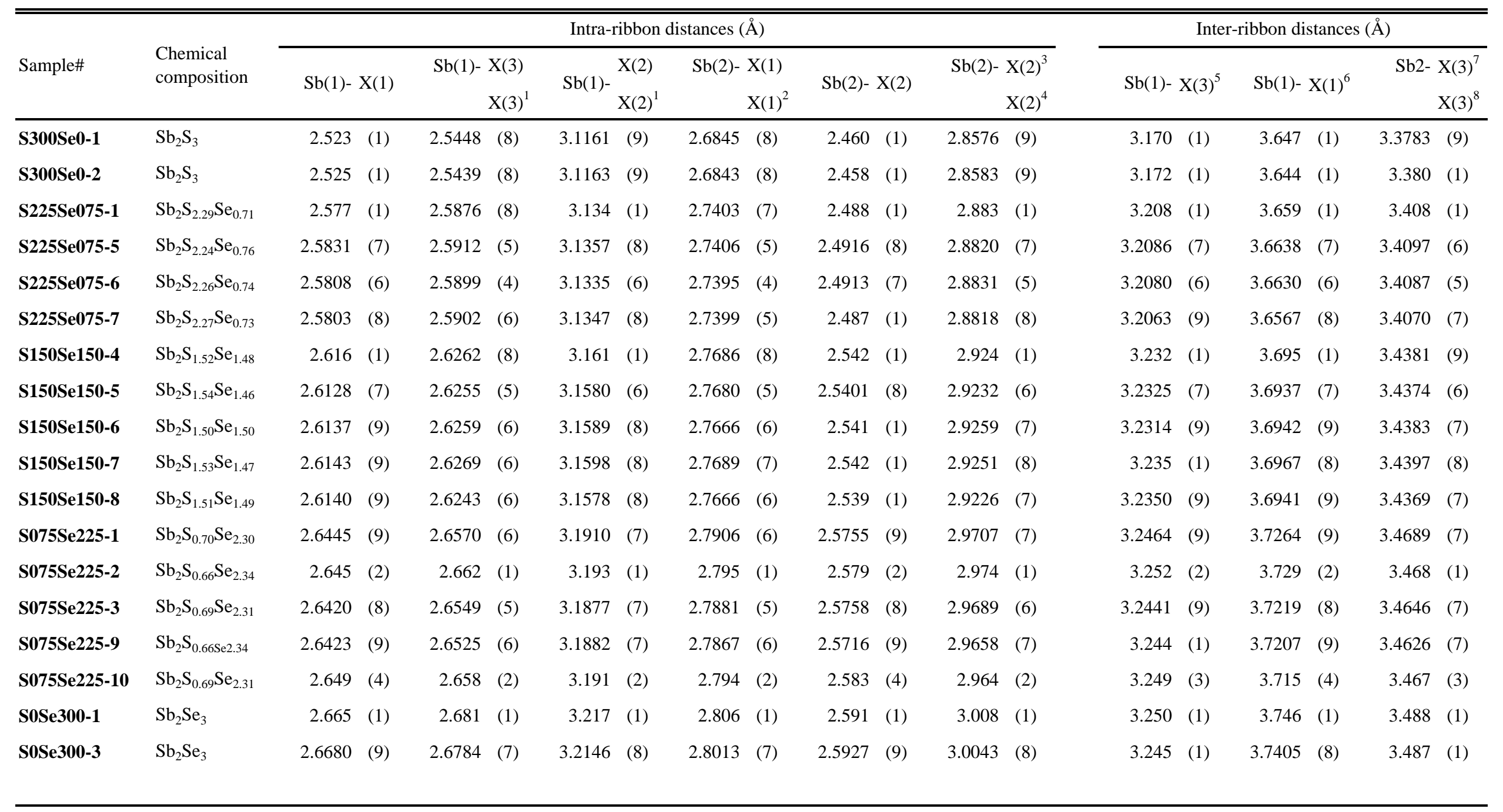

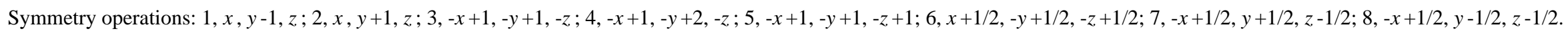

